\title{
Presence of water in residential environments - value for money?
}

Tom Kauko (contact person), Roland Goetgeluk, Ad Straub and Hugo Priemus OTB Research Institute for Housing, Urban and Mobility Studies, Thijsseweg 11 P.O. Box 5030, NL-2600 GA Delft, The Netherlands Phone: +31 15278 7593; telefax: +31 15278 4422; email: T.J.Kauko@tudelft.nl

\begin{abstract}
The role of water in the locational bundle of residential value and choice determinants is multiple. Relevant attributes pertain to water quality, proximity and length of water frontage, view, size of water body, coastal development costs, and costs caused by flooding. They also pertain to different types of water: the sea, lake, river and so on. This is a systematic literature review of the influence of water proximity and use factors on property prices and area attractiveness within a spatial cost-benefit setting. According to the studies that were reviewed the composite effect for water quality, proximity and view generate a price premium up to ca $60 \%$ for seaside property, $25 \%$ for lakeside property, and up to $40 \%$ for a variety of other inland water bodies. In addition, few studies estimate the on-site potential for a coastal area with development restrictions as a net effect of the positive amenity benefits and negative opportunity costs to vary in the range from +21.5 to $-14.5 \%$. On balance these figures point to substantial benefits of water location. However, the price impact of flood risk was quantified separately as up to $22 \%$, and may be deducted from these figures, given a localised tendency for such hazard. Thus, it may be concluded that for the attractiveness potential of a site the environmental externalities play a large role. Furthermore, when allocating housing claims spatially using an operational model where all land uses are covered extra costs to overcome conflict and scarcity situations may arise.
\end{abstract}

Key words: water, amenity, residential, value, choice, benefits, costs. 


\section{Introduction}

In the residential choice literature as well as in the property valuation literature the presence of water is associated with a variety of positive and quantifiable effects. These may be related to quality, recreation (possibility to swim, fish and travel by boat/canoe etc.), ecosystem preservation or groundwater protection, or in a more intangible way to the landscape or specific view seen from the window. On the other hand, flood risk has become an especially serious topic in recent literature, due to bad experiences of flooding rivers.

In this contribution, we focus mainly on the recreational-functional and aesthetic attributes of having access to water in ones vicinity, with the cost aspect (related to development, flooding or external impacts) incorporated as a balancing factor. Our problem is how to identify and possibly quantify these effects. The overall research question can be formulated as follows: What role does water play in determining the attractiveness of water locations, as defined as the choices made and the prices paid by housing consumers? More specifically, two questions are of interest: (1) What is the utility and demand for water environments, as a consequence of changing lifestyles and demographic trends? (2) What are the prices to pay for that element?

The aim is to give an informative presentation on the role of water in the attractiveness of residential environments; hence, a relatively straightforward paper on quantifiable evidence. Some methodological options and dilemmas will be scrutinised, related to comparability of the various studies reviewed. When determining the water value, the idea is to calculate relative weights for water in relation to the total price or utility, based on the literatures of property value modelling and housing preferences/choice modelling. The conclusion is that we discovered methodological difficulties related to conflict and scarcity based costs in trying to determine consumer preferences for the water element, when we based our estimates on all kinds of data available (property transaction prices and other indicators).

In section 2 we present an overview of relevant objectives and approaches. After that, results of a variety of reasonably comparable studies undertaken on our topic are presented in sections 3 to 5. Section 6 summarises the findings and provides a final discussion.

\section{General aspects of water in residential environments to take into consideration}

The US-based literature shows that the role of water in the regional/locational/spatial bundle of attributes is multiple, with examples ranging from salmon migration to hydropower generation to Indian tribal claims (Faux and Perry, 1999). The (use) value of water has several meanings in this context, such as wildlife habitat, angling opportunities and scenic vistas (Bastian et al., 2002), and it is argued that environmental resources are not properly valued in either national accounts or development project appraisals (Choe et al., 1996). ${ }^{1}$ The core issue that underlies this need for information is how locational value and preferences (i.e. utility) can be measured and modelled, feasibly, reliably, and in a valid manner? How have the general methods for measuring preferences been applied for water (proximity) value analysis? Depending on the purposes of the study, one method may be favourable compared to another.

\footnotetext{
1 Today, the territorial competition aspect has become more pronounced, as a consequence of explicit market liberalisation policies. A less constricted housing policy has an impact on national spatial planning, and therefore more interaction between policymaker and individual actor is required. How to take into account the change in consumer behaviour, as the group that appreciates water grows rapidly?
} 
This is because different methods and modelling techniques to some extent operate on different assumptions and therefore provide different conclusions. The following three points will be elaborated:

(1) the underlying methodological position and level of generalisation: intensive/casestudy vs. extensive/statistics; ${ }^{2}$

(2) the way of collecting data, applying Timmermans et al. (1994): stated or revealed choice/preferences (we use this distinction to organise the text);

(3) if a general model is chosen, then what is the unit of dependent variable in the analysis: dis-aggregated choice or average estimate of aggregated demand?

When we review the empirical literature in more detail, we make the distinction between moderate proximity effects (amenity and attractiveness, in general positive), and extreme negative externality effects (flood and drought). Both types may include on-site effects for production, development activity, and other miscellaneous uses. A large literature suggests that a change in environmental amenities can alter the property value (Mooney and Eisgruber, 2001). The price/utility influence related to proximity is the most important effect; the direct use of the site for building, agricultural or other purpose is a secondary, but related aspect.

From the conceptual point of view, the question of interest here is: How does the water factor affect the locational quality/attractiveness value based on pure preferences, which, given a market clearing mechanism at an aggregate level, also is assumed to equal the price? If this assumption is relaxed, the question is reformulated as follows: As the utility in economic terms is a measure of surplus, how then do the prices arise when a measure of constraint is added to the model? In such a market disequilibrium situation the distribution of prices paid is not in par with the distribution of locations in terms of their utility/quality? Then we may distinguish between predominantly price- and quality -based analyses of this effect. An extra element in land price as a compensation for the loss of consumer surplus (i.e. the seller is not willing to sell his property at a value determined by market equilibrium) is indeed recognised in the land economics literature (Balchin and Kieve, 1977; Evans, 1983). A framework, where the use value of the property also includes a non-monetary component has gained even more support lately - to a large extent a result of buyers having become more quality conscious; especially in the Nordic countries, this is a common aspect (Nevalainen et al., 1990; Kalbro, 1994).

From the operational point of view, the relevant questions to ask are: What kind of modelling methods have been applied to estimate market price and perceived utility for water quality, proximity and amount? What kind of empirical evidence (change in value) has been reported, and for what kind of house type or land use, and residents or respondents? What is the validity of the empirical evidence obtained with the hedonic model of the revealed preferences approach in general? How valid are the transaction prices as indicators? Do they capture constraints instead of free choices (cf. Priemus, 1998)?

The various results for an assumed positive effect of water amenity and attractiveness are reported in appendix 1 . Before we take a closer look at these studies, we make a general remark: there are almost always positive estimates for water proximity as a price component.

\footnotetext{
${ }^{2}$ From the point of view of practical valuation application: particular single-property valuation or general massappraisal.
} 
For instance, Viitanen (2002) tells two anecdotes from new developments in Metropolitan Helsinki that show the growing importance of these factors in Finland:

- in one case, the parcel had to be plotted into three different plots; in order to maximise the price of all three, each of them was plotted in such a shape and direction that it had a view facing a nearby lake;

- in another case, the site for a luxurious residential development was designed in such a way that a canal was dug to the vicinity of that site, specifically because of the value premium anticipated.

Apart from the quality of amenities provided by the water body and the view (Mooney and Eisgruber, 2001), also water quality matters. Feenberg and Mills (1980) pointed out that water pollution control has both primary and secondary benefits, if evidence suggests serious diseases to be linked with quality of water. Yet most evidence in the US concern the recreational value of improved water.

Moreover, it is plausible that the impact of water needs to be separated into two elements: a primary, potential-related 'real impact', and a secondary, process-related 'external and latent influence'. In contrast to the former effect, the latter is not generated within a market equilibrium situation, but arises as an outcome of a monopolistic or actor-centred situation. In such situations the market mechanism is distorted as a consequence of the prevailing physical, institutional or behavioural circumstances, and a supply or demand sided extra element emerges within the price formation. Another difficulty is that in both cases we deal with the inter-connectivity of many factors, and not each factor isolated. Therefore, we need to pick out fuzzy bundles of concepts that may point to several items.

To conclude, we need new information about the role of water in housing choice and the formation of house prices. On a general level, water indeed has a value related to amenity or other classic externality effect, but we also suspect that the overall value is compounded by different elements: partly commensurable, and partly incommensurable ones. The problem then becomes to identify these empirically. For this purpose, there is a variety of approaches that involve conceptual as well as technical aspects. In the remainder of the paper, we review the evidence obtained from a set of studies with regard to the attractiveness of water locations - in most cases treated as an economic shadow price.

\section{Standard amenity impact studies}

\subsection{Introduction}

Because of our aim to when possible focus on the preference side of the market clearing, we choose the following order in our account of results obtained:

(1) 'pure preference' ranks (or ratios);

(2) willingness-to-pay (WTP) estimates obtained from stated preferences;

(3) shadow prices obtained from revealed preferences. 
Most of the studies are summed up in appendix A. Due to the small number of stated preferences studies compared with revealed preferences ones, the studies that apply both methods ${ }^{3}$ are included in the groups (1) and (2).

\subsection{Stated preferences and multidimensional value}

The tradition of modelling pure preferences (i.e. no price information is used in the elicitation) related to water has a number of relevant contributions. For the landscape aspect, various surveys on environmental preferences/perception were cited in Ryan (1998) as follows:

- $\quad$ Kaplan, 1977: Park-like sections of a river stream were preferred to sections that were immediately adjacent to homes, so the spatial proximity does not always increase preferences for a particular water amenity;

- $\quad$ Levin, 1977: Curving river scenes and river scenes through open trees were preferred to other river scenes;

- Herzog, 1985; and Ellsworth, 1982: Spaciousness of water scenes played a role: Lakes were preferred to rivers, which were preferred to marshes. (Mahan et al. found the opposite order of the last two types of water body, see below).

Ryan (1998) explored the rural residents' preferences for given micro-locations related to a riparian river corridor and values that the respondents attach to the various components of the landscape. The approach was described as holistic: based on a survey, where the preferences for certain amenities were elicited with a scale from one to five. According to the results, newer residential owners preferred the natural landscapes over the domesticated elements of the scenes compared to long-term residents and farmers, who had a preference for less natural landscapes. Furthermore, river scenes were the highest in preference, overgrown stream scenes the lowest in preference, distance to the river was related to problems with water quality, and respondents opposed new development in the area.

Krausse (1995) studied the effects of tourism and waterfront renewal on the perceptions of harbour residents in Newport, Rhode Island, New England and concluded that the effect was both positive and negative. According to the results, too many visitors and too much development contribute to a negative image, and consequently to a reduced attractiveness of the site; visitor - resident tensions are conflicts between community social carrying capacity and development objectives such as a cruise-ship pier and a marine terminal); $83 \%$ of the respondents want more access to water, but only $1 \%$ agree that it should be implemented via parks, marinas or housing projects.

In a sense, the results are similar to the ones obtained by Schalken (2002) from the Netherlands: crowdedness is a strongly offsetting factor in relation to positive effects such as leisure and aesthetic values. Heins (2002) recently analysed rural preferences in the Netherlands using a decision plan net (DPN). According to her results, water proximity is present among the locational attributes that the consumer considers, without being among the most important ones, such as possession of a garden.

Bender et al. (1997) applied an approach based on the analytic hierarchy process (AHP, Saaty, 1977) for multidimensional evaluation of perceptions concerning the environmental quality in Geneva, Switzerland, using a questionnaire to house owners about the relative

\footnotetext{
${ }^{3}$ That is to say, comparison of or triangulation with stated and revealed preferences.
} 
importance of various environmental attributes using a link to a GIS. Distance to green areas including rivers and lake was found the most important attribute with a weight of $18 \%$.

The results from the limited 'pure' preference models are difficult to summarise in a way that allows comparison with results from the other studies (discussed in subsections 3.3-4 below). Nonetheless, presence of water was undoubtedly confirmed to be a factor of significant relative importance in these studies that we consider as state of the art, but often isolated and experimental projects. The added value of this group of methods is the possibility to go into a great detail (beyond monetary costs and benefits) about the role of particular factors, notably the amenity value of landscape and leisure opportunities, as well as the negative images related to anticipated coastal development projects.

\subsection{Stated preferences and willingness-to-pay}

As opposed to the studies reviewed above, a handful of stated choice/preference techniques (contingent valuation and certain variants of conjoint choice) operate on assumptions of the willingness-to-pay or willingness-to-accept of rational consumers, and thus arrive at an economic target variable.

Mäntymaa (1993) investigated the utility of a lake water quality improvement in Finland using contingent valuation. The respondents were owners of parcels. Mäntymaa estimated annual payments to ca. $€ 90$ for one point quality increase; and ca. $€ 130$ for avoiding one point decrease. Indeed, one tends to value less a hypothetical increase, than a hypothetical decrease. Furthermore, recreational fishers and owners of second homes gave substantially higher WTP than forest owners. (The problem was that some persons belonged to both groups.) According to the results, a higher income increases the WTP, and 18-29 years old pay more than others. To evaluate, whether the amounts are substantial or not, we related the results from this study to the annual income in Finland in 1994: ca. $€ 1$ 15,000.Thus, the estimated WTP for the whole sample amounts to less than $1 \%$ of the annual income. Moreover, model inconsistencies were addressed in this study.

Magat et al. (2000) studied the iterative choice regarding inland water quality, using a structured interview approach (similar to conjoint choice). The choices between two regions that comprise different water quality and living cost packages were asked iteratively through a series of tradeoff questions. These questions were broken down and paired comparisons between the options were specified in detail, until a point of indifference was found. Water quality was understood as a measure of safety in terms of swimming, fishing and boating in the lake or river. Interestingly, they explicitly excluded drinking water from the questionnaire under the premise that water treatment plants ensure a safe drinking water. ${ }^{4}$ Lake water was more preferred than river water. The monetary values reported were not high, when related to family income.

Willis and Garrod (1993) compared hedonic estimates with contingent valuation estimates and found conflicting evidence: the estimated value premium for frontage was $2 \%$ when using

\footnotetext{
${ }^{4}$ The drinking water problematic is revisited in a few studies, but we have excluded them from this account. Drinking water obviously should be the most obvious topic within hydrology. It has been studied in areas, where it is a relatively scarce resource (see e.g. Lynne et al., 1991). Here we note that in developed countries the added value of water is primarily derived from view and recreational opportunities; not drinking water contamination, which by and large is assumed away. This creates obstacles for the transportability of the method to substantially different parts of the world, where the sole problem worth mentioning is the drinking aspect (cf. Choe et al).
} 
the hedonic models, and 24\% when using contingent valuation. The former measure included some downwards bias (due to aggregation over microlocations where the water location is not present or negligible) and the latter some upward bias (for several reasons, not the least related to selectivity). The real appreciation was closer to the hedonic model predictions, the authors argued.

Earnhart (2001) combined discrete-choice hedonic analysis (revealed preferences) and choicebased conjoint analysis (stated preferences) in order to estimate the aesthetic benefits generated by environmental amenities associated with residential locations. The combined approach was applied on an improvement in the quality of coastal wetlands due to restoration. (This was also a hybrid between aggregated and dis-aggregated techniques.)

Smith (1993) cited the following studies (1985-92), where different methods have been compared:

- $\quad$ Seller, Stoll and Chavas: value of four lakes for boating; link was found between travel cost and discrete contingent valuation;

- $\quad$ Smith, Desvousges and Fisher: water quality; travel cost (dissolved oxygen) vs. contingent valuation (quality ladder); link was verified;

- Lomis: willingness-to-pay to preserve the water level of Mono Lake; contingent valuation over time; general population survey vs. sample of on-site visitors;

- Duffield and Patterson: in-stream waterflows as habitat for fish; different contingent valuation samples.

Proximity and access to better quality water among people in Davao, Philippines was studied by Choe, Whittington and Lauria (1996); contingent valuation and travel cost estimates were close to each other and quite low; hence a low willingness among these residents to pay for improved water quality.

In a study aimed at quantifying the amenity benefits of farmland, Ready et al. (1997) found that coast location (a coast dummy for whether the county of residence touches an ocean or a Great Lake was used as a control variable) increases monthly housing expenditures, and at the same time decreases the hourly wages.

Although difficult to conclude based on such small sample, conjoint choice and contingent valuation are more substitutes for hedonic and travel cost methods, than for the methods aimed at pure preference modelling, even though they use stated preferences for data collection. The problem is however to find a measure to compare these results, if no property price data are involved in the study. We also note that the methods that are dealing with economic value offer only limited aid to examine context specific and interactive effects.

\subsection{Revealed preferences}

\subsubsection{Situation by and proximity to shoreline}

Laakso $(1992 ; 1997)$ concluded that, in metropolitan Helsinki, location in the vicinity of the coast generated a 25-30\% premium. Moreover, he estimated (using dummies and spline functions) the price difference to $50 \%$, between similar houses situated on the coast and 1.25 $\mathrm{km}$ from the coast. He also concluded that the price decreases more steeply with distance in outer than in inner parts of the city, because in the inner part of the city there is an abundance of coastal areas whereas in the outer part coasts are not easily accessible (i.e. the scarcity 
value of water). In contrast, Tyrväinen (1997) only modelled a part of Joensuu housing market where water was abundant and did not get that strong price effect.

Geoghegan et al. (1997) applied a logarithmic hedonic price model based on spatial landscape indices, with waterfront as a control variable. The model predicted $40 \%$ increase if the waterfront dummy was on.

Shultz and King (2001) studied the proximity to rivers and streams that are often dry for most of the year. The class I habitat had a negative proximity effect on price, ostensibly due to flooding and insects (cf. Kaplan's argument above). Class II had a positive price influence. Furthemore, this variable was found very sensitive to reduced sample sizes.

Rush and Bruggink (2000) found that ocean or bay location, either measured as frontage or proximity, brings a considerable price premium for property on a narrow barrier island. In the case of barrier islands, the metric distance is a more important price determinant than the view. A house with an ocean frontage of 50 feet is worth $\$ 431,000$, whereas a similar house located 11 houses away from the ocean is worth $\$ 205,000$. Moving the house 8 houses closer to the shore would add $\$ 61,000$. Furthermore, the magnitudes reported did not differ significantly between the hedonic models based on transaction prices and assessments.

Gartner and Chappelle (1996) presented a hedonic model based on owers' estimates of value for recreational property (land and dwellings) in three Michigan counties. He used a technique similar to the hedonic price methods, but based on survey responses from ca 2,000 owners of recreational property instead of market price data. The location at larger lakes was found to increase the value per acre as follows: $\$ 32,000$ for permanent homes; $\$ 16,000$ for seasonal homes by a $25-100$ or $500+$ acres lake; $\$ 40,000$ for seasonal homes by a 100-500 acres lake. Furthermore, when plenty of opportunities for locating the property near water exist, only particularly attractive water locations increase the value; in other words, some water bodies are preferred over others.

In standard hedonic studies the price increase of water amenity and/or proximity (as measured through distance or location based control variables) has also been found by Li and Brown (1980). The value of wetlands amenities was also studied by Mahan et al. (2000), who applied a two-stage hedonic approach ${ }^{5}$. They concluded that wetlands influence the property price differently than other amenities. The size of the wetlands and its proximity matters, but not the type of wetlands. (See also Bennett et al. 1998; and Acharya and Bennett 2001; who conducted a hedonic analysis of residential property values in the New Haven watershed system, US, using data on 4,000 homes, and variables for open space, land use diversity and other general environmental variables.)

Kauko (2002) included the location in the vicinity of a water body (sea coast, river, lake or pond) to his neural network -based analysis of Metropolitan Helsinki. He picked two locations that were of same magnitude in all other characteristics, but differed with respect to shoreline proximity: one located on an island, and another as far away from any water as possible. This way, it was possible to calculate the difference in price per sq.m. between these two locations. The price premium in favour of the island location was $12 \% .^{6}$. In the same

\footnotetext{
5 In this method, the hedonic price model represents the first stage. In the $2^{\text {nd }}$ stage WTP estimates are derived for a priori specified consumer groups based on the coefficients estimated in the first stage

${ }^{6}$ This is substantially lower than the result above by Laakso, which however was related to a direct or immediate vicinity to coast location - a more exact measure than Kauko's aggregate for the whole subdistrict in question.
} 
study Kauko continued with a similar analysis of Amsterdam. Using a crude technique ${ }^{7}$ some overlap between presence of water and expensive areas was observable. However, a clearer association was found between more water and a lower density. Furthermore, a situation by a canal showed up and generated a price premium - but not always.

\subsubsection{View}

Mooney and Eisgruber (2001) cited three hedonic studies (1993-96):

- $\quad$ Lansford and Jones, residential property, Highland Lakes, Colorado river basin, Texas; scenic view increased the price by $8 \%$;

- $\quad$ Kulshreshtha and Gillies; consumers were willing to pay a premium for house with a river view in Saskatoon, Canada;

- $\quad$ Streiner and Loomis, property value increased \$ 4,500 - \$ 19,000 in areas of Colorado with restored urban streams (we estimate this to $4-15 \%$ ).

Benson et al. (1998) focused specifically on ocean and lake views, and how these interact with distance to the shore. They found a 8-60\% premium for the highest compared to the lowest quality view. Furthermore, they found that the value of an ocean view rose in the late 80 s, during a period of market upswing.

Fraser and Spencer (1998) found out that the best ocean view increased the price 25\%; a better view increased the price, but with a diminishing rate (marginal utility).

Luttik (2000) estimated shadow prices for environmental factors in three different Dutch localitites (Emmen, Apeldoorn, Leiden). In this study all 3000 observations were visited, which makes the dataset used a particularly reliable one.

Kyllönen and Räty (2000) got clear results for price premium of shore view in a hedonic study on the Joensuu housing market (cf. Tyrväinen did not obtain a price effect using shore view and data from one market segment from the same city).

Lake et al. (1998) used the distance to a water-body as a control variable in their hedonic model using very sophisticated procedures involving an extensive GIS.

Orford (1999; 2002) applied multi-level specifications (i.e. property-level, street-level, district-level, community-level) of a hedonic model for the Cardiff housing markets and for valuation of locational externalities in a part of the city. He focused on proximity variables, constructed as interval dummies, based on measured distances to rivers; 4 buffer zones of $50 \mathrm{~m}$. from the river. Estimates are reported as follows: proximity of river (property level) adds $£ 9000$ (20\%), if situated within 50m (1th buffer zone).

Wilhelmsson (2002) utilised a spatial extension to hedonic regression modelling and included the sea view as a binary dummy variable, which is found logical (i.e. to increase the price of

Besides this, whereas the hedonic approach is aimed at isolating price factors, this approach is aimed at capturing composite effects.

${ }^{7}$ The presence of water was measured and visualised with a water indicator label defined as the ratio of 'Sq.m. of area including water' and 'Sq.m. of land area'. It took values between 0 (no water) and 1.9 (almost half of the area covered by water). 
the property) and significant. With the spatial specification the sea view brings a $26 \%$ price premium (even 40\%, with the standard model, which as the author suggests is a biased result). Pollard (1982, cited in Wolverton, 1997; and Benson et al., 1998) came up with an interesting finding: that lake views, apart from increasing rents $7 \%$, also tend to lead to taller buildings being built on the shore sites (some other studies found evidence for the opposite relationship).

\subsubsection{Water quality}

Poor et al. (2001) compared objective, scientific measures of water quality with subjective measures of individuals' perceptions, when used as independent variables in hedonic models and concluded that the former type provide at least as valid explanation of the variation in sales prices as the latter.

Melissa Boyle and Kiel (2001) cited seven US-based hedonic studies on water quality (19682000) and concluded that water quality studies consistently find the correct sign for the estimated coefficients; in general, the results were significant. It was found, among other things, that

- rural, non-farm communities perceive water quality (and flood hazard) to have a significant effect on value: one point increase in $\mathrm{pH}$ brings a 5.9\% increase in mean price;

- water quality has an interaction effect with population growth;

- location within the bay reduced the value by an average of $20 \%$;

- improvement in clarity increases sales price significantly, when measured with Secchidisk readings (number of feet below the surface that a device which is 8 inches in diameter can be observed)

- homes whose nearest waters were affected by PCB were substantially lower in value;

- increase of fecal coliform $(100 \mathrm{count} / 100 \mathrm{~mL})$ caused a $1.5 \%$ reduction in property value.

Kevin Boyle and Taylor (2001) conducted a comparison between recorded tax-assessor data and perceived/survey data from purchasers of properties with frontage on 34 freshwater lakes and ponds in Maine (threatened by organic enrichment). The hedonic model was partitioned into four location specific market groups. Lake-water quality, measured with a Secchi disk in the summer months during the year of transaction was found significant and the magnitudes were not different: the impact varied $\$ 2,000-8,000$ per meter of clarity depending on the segment.

Peltola's (1998) study concerned the price factors of large shore-parcels (unbuilt, no town plan, use as holiday site). The results showed that not only the quality of the water, but also the quality of the shoreline/beach (i.e. suitability for building, shape and length) matters for the price formation of nearby properties. Furthermore, the time of sale was important (as in the study by Benson et al. above); apparently, during 80s investors bought valuable beaches more than in the 90s. No price effect was found for the quality of submerged shore 1..4, nor for quality of water, visually evaluated with the scale $1 . .3{ }^{8}$ (See also Rinehart and Pompe, 1994; who approximated beach quality with the beach width.)

Many of the market price based studies above suggest that for urban areas the positive water proximity effect is first of all present, and second, it is strongly related to the scarcity aspect: for the housing market as a whole, and as a steeper distance decay, where the water is a scarce

\footnotetext{
${ }^{8}$ Measured with a GIS, Peltola rarely found more than $2 \%$ price increase for any specific amenity variable. However, Peltola used values of land, not houses, as dependent variable.
} 
amenity. More or less the same goes for second homes in the countryside; monetarised effects related to various attributes of the coast and the water body, as well as time of sale.

\subsection{Impact of coastal protection and development activity}

In some cases the water amenity is strongly present not just as a proximity effect, but actually on-site as well. Then, the cost side related to (lost) development value potential has to be included in the model. How much does a given planning restriction then encumber or facilitate the development of the affected site, and to what extent is this impact offset by a potential amenity effect?

Del Saz-Salazar and Garcia-Menendez (2001) applied contingent valuation on the value of environmental improvements derived from developing port-areas for recreational purposes (over three years) in Castellón, Spain. Based on their reported estimates, we calculated that even if payment of all three years are made in one year, the amount that Spaniards are willing to contribute is very modest (below 1\%). The findings are nevertheless significantly correlated to age (negatively), income, the expected use of the new recreational facilities, and subjective value given to the project.

Dale-Johnson and Yim (1990) on Los Angeles County, and Spalatro and Provencher (2001) on Wisconsin provided an assessment of planning controls on property value, related to shadow prices for amenities. They found that the economic net cost or benefit of minimum frontage zoning on lakefront property is a sum of competing effects: constraining the development means a loss, but preserving environmental amenities means a gain. Evidence showed that the net effect is a substantial price increase (in the latter study $21.5 \%$ ), in other words, the positive amenity effect was the more substantial of the two hypothesised effects.

Parsons and $\mathrm{Wu}$ (1991) pointed out that population migrations in US to coastal states bring concerns about increased development. Then state land use controls that limit new development on land adjacent water are applied. This enables estimation of the cost of displaced residential development or lost access to coastal amenities. They approach the estimation as follows: first, they find a comparable housing market area, from where they derive a hedonic function with shadow prices for the amenities unique to the coast; then, they predict the number of houses that are 'displaced' from the coastal area; finally they use the hedonic model to estimate the total loss resulting from the land use control - the opportunity cost. The average annual losses in Chesapeake Bay, US, 1986-2005 were depending on the scenario estimated to 1.2-19.1 million dollars (up to 14.5\% of the total value of the houses in the area). This way it was shown that the various coastal planning controls not only bring an amenity value, but also cause a restriction with monetary shadow costs.

\subsection{Contamination and wildlife protection}

Within the same problem area, contamination and wildlife protection offer another topic with increasing importance. Here we see the shadow cost and concrete cost perspectives.

Mooney and Eisgruber (2001) assessed the influence of a strip of vegetation that buffers the stream area from adjacent activities (aim in water quality and fish preservation), a 'riparian protection buffer'. While having some long term benefits, this buffer interferes with the river view, and also has other negative effects on the market value of the parcel situation by a river. 
Using a hedonic model of property values in the Mohawk watershed, western Oregon, the corresponding price reduction was estimated at $3-11 \%$.

Van Kooten (1993) evaluated the impact of wetlands retention on a typical farm in southeastern Saskatchewan, Canada, and estimated the shadow price for marginal land to \$ 50-60/acre. This is twice as much (i.e. $+100 \%$ ) as compensations to farmers. ${ }^{9}$

Lovell and Sunding (2001) studied voluntary development restrictions and the cost of habitat conservation. Also here the hypothesis was that pre-existing development restrictions affect the cost of habitat. The case was about preserving vernal pools in California's Sacramento county. The existence of surface water on or adjacent to the parcel was incorporated into a hedonic probit model of agricultural land parcel sales/assessments (dependent variable: enrolment or not). Significant correlation was found: less water increased the likelihood of being enrolled, and the land value increase was correlated with enrolment. Thus, water amenity not only has the more direct effects, but also some more indirect ones, related to environmental protection purposes.

\subsection{Summary and dis-aggregation of the studies on amenity effect}

The fact, that different methods are used in different contexts makes it more difficult for us to make conclusions in a quantitative sense. We would like to find studies that apply the multidimensional value framework from European areas, but instead the majority of the studies are made by the hedonic approach from the US. This is not to deny that the latter may be the most sophisticated, but the economic equilibrium aspect certainly is not always realistic. So the most preferred types of studies are too few. Nevertheless, below we aim at a comprehensive overview, drawing on usable elements from each study. We start the summary by geographical context and general approach used (see table 1; note: one and the same study listed in appendix 1 may have used two different approaches; and data from two different countries):

Table 1 Studies reviewed broken up by approach applied and geographical context

\begin{tabular}{|l|l|l|l|l|}
\hline & Total & $\begin{array}{l}\text { Stated } \\
\text { preference/choice, } \\
\text { multidimensional } \\
\text { value }\end{array}$ & $\begin{array}{l}\text { Stated } \\
\text { preference/choice, } \\
\text { economic value }\end{array}$ & $\begin{array}{l}\text { Revealed } \\
\text { preference/choice }\end{array}$ \\
\hline North America & 28 & 2 & 2 & 24 \\
\hline UK & 3 & & 1 & 2 \\
\hline Australia & 2 & & 2 & 6 \\
\hline Nordic countries & 7 & & 1 & 2 \\
\hline The Netherlands & 5 & 3 & & \\
\hline Other Europe & 2 & 1 & 1 & 1 \\
\hline Other & 1 & & & 35 \\
\hline Total & 48 & 6 & 7 & \\
\hline
\end{tabular}

\footnotetext{
${ }^{9}$ Van Kooten surveyed farmers and calibrated a theoretical model of grain producers when they act to maximise their net wealth in the face of government agricultural programs that aim at reserving a portion of the area for waterfowl habit. As the problem here is relevant for our topic, we decided to include this paper in our review, although it does not deal with residential land.
} 
We examined the Netherlands context and study tradition in particular. In the studies conducted in the Netherlands the abundance of water shows up very strongly, although two studies (Priemus, 1998; Luttik, 2000) found evidence for relatively strong importance of the water as a general aesthetic attribute; in particular, two Dutch studies applied a stated preference/choice approach with an explicit floating home perspective (Schalken, 2002; Heins, 2002) instead of the approach found in the international literature that uncovers effects of water and beach quality, view and proximity effects. We can also point out other interesting differences between the mostly American hedonic type and the Dutch 'pure preference' type: (1) notably the differentiation of preferences along consumer types in the latter, perhaps simply because some of the methods that are popular by the Dutch researchers are particularly dis-aggregated and allow for the differentiation better than most other studies; (2) the amount of available alternative locations (with or without water) is limited in a large part of the country; and (3) due to the very constrained Dutch land use context, it is more than in other studies reason to believe that the amenity effect at times reverts to a disamenity effect - this depends on the amount of safety, privacy and general 'pleasantness' that comes with the water environment package.

In general the Dutch studies point to a very differentiated relationship between water and price; it is highly dependent on other factors, such as area density, the presence of sewers and images related to the development potential. In Luttik's proposition different scale levels ranging from small decorative canals to large lakes, as well as the premiums of waterfront, view and proximity, may all be handled in the same additive model, which probably is a valid point specifically in the Dutch geographical context.

Below we try to calculate the value for each amenity or proximity attribute separately. On balance the amenity/proximity effect is registered in so many studies that we conclude that it is reality. The dichotomy between stated and revealed preferences methodology that we emphasised is also not too problematic for our review. However, problems arise in the comparability between quantifiable effects: whether the price increase of a good view, proximity to water amenity, improved water quality and so on are reported in absolute or relative terms, as well as the exact definition of variables. ${ }^{10}$

Even though we acknowledge the problems involved, we had to try to standardise the findings as generally as possible. When ranges are reported, we used them as a lower and higher bound for a given effect, depending on technique and units of measurement. Price and multidimensional value in both cases are dealt with as a percentage relative increase/decrease (except for survey and contingent valuation -studies, where we do not really have a base amount to compare with, but for our purposes we use income when estimating relative increases); then if only absolute values are reported, we have to estimate the relative value based on mean values. ${ }^{11}$ If no mean values were reported in the study in question, we used mean values from other studies in the same country, and if necessary with time indexed to the time of study (see Boyle and Kiel, 2001). Then we calculated the relative increase/decrease based on that value. Such manipulations and approximations may seem crude, as they undoubtedly increase the error margin of estimate. They are however better than no estimates at all.

\footnotetext{
${ }^{10}$ Unfortunately, we do not have an EU or UN-initiated standard of environmental amenity measurement.

${ }^{11}$ The beta-coefficients are not a useful criterion for comparison either, because of the various logarithmic and other transformations applied.
} 
We can now summarise the estimates for water amenity/proximity as follows. To start with, it is obvious that at least one particular amenity effect is verified in all but one study (i.e. in $98 \%$ of the studies). We have reported some ranges for each type of effect for the studies with quantified results in table 2 . We have disaggregated the effects by four types of water and four types of effect. If a complete dis-aggregation by size of water and/or effect was not possible, we have assigned the same preference or price estimate to more than one category. Using reported or estimated mean values, we have estimated the relative increase in price, annual income or other attractiveness rank/ratio. The amounts in brackets are based on (questionnaire) surveys and related to income or compensation; measurements reported as ratios or ranks are in italics.

\section{Table 2 Estimate ranges broken up by objective and type of effect}

\begin{tabular}{|c|c|c|c|c|}
\hline & Sea (incl. ocean) & $\begin{array}{l}\text { Lake (incl. ponds } \\
\text { and artificial } \\
\text { lakes) }\end{array}$ & $\begin{array}{l}\text { Rivers, streams, } \\
\text { and other inland } \\
\text { waterways (incl. } \\
\text { canals) }\end{array}$ & $\begin{array}{l}\text { Wetlands, marshlands } \\
\text { and other water bodies } \\
\text { with lesser recreational } \\
\text { value }\end{array}$ \\
\hline $\begin{array}{l}\text { Water quality } \\
\text { (comparison with the } \\
\text { unpolluted situation) }\end{array}$ & $+20 \% . .30 \%{ }^{12}$ & $\begin{array}{l}+0.1 \% . .8 .2 \% \\
\text { (WTP/income: } \\
+0.9 \% \text { ) }\end{array}$ & $\begin{array}{l}+5.9 \% \\
(+0.9 \%) \\
(\text { rank: } 3.57 / 5)\end{array}$ & \\
\hline $\begin{array}{l}\text { Direct waterfront } \\
\text { (dummy) }\end{array}$ & $\begin{array}{l}+0.3 \text {.. 30\% } \\
(42 \% \text { of } \\
\text { respondents } \\
\text { believes in a } \\
\text { price increase) }\end{array}$ & $+11 \% . .12 \%$ & $\begin{array}{l}+2.6 . .40 \%{ }^{13} \\
\text { (rank: } 3.24 / 5 \text { ) }\end{array}$ & $+40 \%$ \\
\hline $\begin{array}{l}\text { Water/shore proximity } \\
\text { (one relative/relevant } \\
\text { unit closer) }\end{array}$ & $\begin{array}{l}+1.5 \% \text {.. } 30 \% \\
\text { (83\% wants } \\
\text { water proximity) }\end{array}$ & $\begin{array}{l}+4 \% \text {.. 10\% } \\
\text { (weight 9\% .. } \\
12 \% \text { ) }\end{array}$ & $\begin{array}{l}-0.06 \% \text {.. }+20 \% \\
(\text { rank: } 4.25 / 5)\end{array}$ & $\begin{array}{l}+0.3 \% \\
(30 \% . .39 \% \text { puts strong } \\
\text { importance in water } \\
\text { proximity) }\end{array}$ \\
\hline Water/shore view & $+8 \% . .60 \%{ }^{14}$ & $+7 \% . .25 \%$ & $\begin{array}{l}+3 \% \text {.. } 28 \% \\
\text { (rank: } 3.88 / 5)\end{array}$ & \\
\hline Water size (ha, acres) & & $+2 \% . .307 \%$ & $<+0.02 \%$ & $+0.02 \%$ \\
\hline
\end{tabular}

Coastal land use development or protection

$$
\begin{aligned}
& -14.5 \% \text { opportunity cost } \ldots+21.5 \% \text { amenity } \\
& \text { effect } \\
& (-100 \% \ldots+0.8 \%)
\end{aligned}
$$

The water quality effect (quantified effects from 10 studies are reported) is measured with either subjective or objective indicators; it is in some studies evaluated visually based on judgement (i.e. scale or dummy based on perceived quality), but it is also (depending on feasibility criteria) measured with a Secchi disk instrument, or $\mathrm{pH}$ and pollution levels. Following the guidelines by Feenberg and Mills (1980), at least two quality variables, a crosssection instead of time-series, and discrete choice estimates instead of OLS regressions, are recommended as methodological choices in studies of amenity impact on water quality.

\footnotetext{
${ }^{12}$ In one study $+1.5 \%$ was reported for 'fecal coliform count' that is coliform concentration above median levels, but it was not clear how to relate it with the results from the other water quality studies.

${ }^{13}$ In one study the effect was negative $(-17.5 \%)$ and ostensibly related to various nuisances that this variable correlates with, but is not meant to capture.

${ }^{14}$ In one study $+7 \%$ was reported using undeveloped land price instead of house prices.
} 
The proximity variable (20 studies) seemed particularly difficult to standardise for comparison; the idea is to find a measure that describes how close to the beach the house or parcel is located. Therefore, we split this factor into direct frontage (i.e. zero distance, the house is located by the water) and then situations, when water is found in the vicinity, at a perceivable distance, which depending on the case, may be tens or hundreds of meters. In the latter case, we estimate the effect per relevant unit as a relative distance measure, for example $\mathrm{n} \times 10 \mathrm{~m}$., $\mathrm{n} \times$ houses from the beach, or a lake being located within the boundaries of the same county. Thus, we give a very broad range of definitions for the reported percentage effect.

The view factor (10 studies) as such is the least problematic of the proposed measures, as it represents a predominantly subjective attribute. One cannot even attempt to measure it as exactly as the other effects.

The size of the water body in question (3 studies) is measured as a comparison with a lake or river of a substantially larger category. Although this effect obtains the highest percentages of benefit impact, it is the least important of the amenity-based effects, when comparing the results listed in the table above. In two of the studies the dependent variable is land value, not house price, which means that the relative contribution of the effect then is larger than if it was reported for a built-up property.

As a separate group we summarise the 6 studies with coastal development aspect (reported in sections 3.5-6 above), even though they may combine it with an amenity effect aspect.

Even though some studies showed that it is possible to treat the various effects in a additive way, it is however likely that in most cases the effect of one successfully isolated variable proxies for one or more other effects. For example, water quality is used as only variable, and the four other variables may eat some of the explanatory power. Therefore, we also calculated the water amenity as one and the same composite effect for water quality, proximity and view: the range for price premium is then from $0.3 \%$ up to $60 \%$ for seaside property, from 0.1 up to $25 \%$ for lakeside property, and up to $40 \%$ for a variety of other inland water bodies. Furthermore, we may conclude that the WTP for such improvement is very marginal, but that locations in the vicinity to water bodies are considered attractive choices to at least a certain proportion (30-83\%) of the housing consumers, when compared to other locations, and that high quality ranks are assigned to the water attribute, when it is included among the list of potential determinants of locational choice and attractiveness. Finally, we note a significant influence of an on-site use. This may be a benefit contributable to the amenity effect, an extra cost related to a lost opportunity, or a net effect of these two elements.

The last problem was to look for a connection between the effects above and various segments of the affected population (either types of respondent or types of land use). Because of the nature of the studies, which is predominantly aggregate level analysis, such results are not reported consistently at all. For population segments the results are modest and we have to draw on only a few of the studies reported.

As a general rule, property owners are older, wealthier and have a larger household size than the household mean figures. Minority groups are especially affected, and fishers and owners of seasonal/2nd home express substantially a higher WTP than forest owners. Furthermore, higher income groups and 18-29 years old are willing to pay more than other respondents. 
A fraction of the studies also indicated some subjective values and the lifestyle factor. It was interesting to see that, whether the respondent had visited the lake during the year before, also was a relevant factor. A somewhat related aspect is that recreational property, second homes and also houses situated on barrier islands are more sensitive to water amenity effects than permanent dwellings.

We may highlight the idiosyncratic, nonlinear and differentiated relationships found in the survey to eight points. First, distance decay and accessibility in relation to time, CBD-distance and water pollution levels generate a scarcity value in an urban setting.

Second, how to abate disturbance related to congestion, when a coastal or river area becomes too popular? This brings extra costs to the overall balance sheet to make the profitability estimations less optimistic.

Third, within the four categories for water some more particular types of water (aesthetic and spacious, for example) may indeed be preferred over others.

Fourth, these general effects were not the same in all studies - there are always exceptional circumstances. Proximity to a more natural habitat may have the opposite price impact than expected, and it may be preferred to keep a certain minimum distance to a predominantly public amenity such as a river stream. The urban equivalent to such disamenity effect is that a polluted and small canal may be considered unattractive, and then this cost generating element is impossible to separate from the benefit of a situation by the same canal. (In section 4 we have made a separate account of the case of flooding.)

Fifth, consumer surpluses may also have an impact on people's income requirements. Amenity is not just capitalised as higher house prices, but also as lower salary requirements. If the income variable is latent, the estimates for the attractiveness/value of water presence may be biased.

Sixth, in general the willingness-to-pay proved to be an uninformative measure when asked, and we recommend using a multidimensional value setting for future research designs. Either percentage, or a quality rank $1 . .5$, for example.

Seventh, sites with maximum price or attractiveness effects are rare, so there are reason to believe that any effect is closer to the more conservative value of range. In our case that would be $10-15 \%$ for seaside location, about $5 \%$ for lakeside location, and $5-10 \%$ for other water-bodies.

Finally, the implications for land and building developments were ambiguous: sometimes water proximity seems to generate higher and sometimes lower density development.

\section{Extreme negative externality effects: flood and drought}

Given the recent dramatic flooding of rivers in Central Europe, it is relevant to include the natural hazards (i.e. flood risk and other related factors as well as its opposite drought) as negative externality effects related to water proximity. Americans too remain vulnerable to floods, as fatalities from these disasters have remained relatively constant despite improved hazard management practices (Wernstedt and Hersh, 2001) ${ }^{15}$. The above cited study by Shultz

\footnotetext{
${ }^{15}$ For a hedonic price model to evaluate flood insurance in the US, see Shilling et al. (1989).
} 
and King (2001) found, perhaps surprisingly, that of two rivers, a river which is more pristine and biologically important to wildlife species, has a negative price influence. They suspected the reason to be that such first class habitat is more likely to be flooded. As the study in question only dealt with a dried out riverbed, this leads us to believe that in some locations close to larger bodies of water this negative, cost generating side of the water proximity effect is even the most relevant objective to study.

Flood risk related estimated results are reported in appendix 2, similarly as with the amenity results above. We assume that the impact is severe and negative, and either directly related to the occurrence of a local flooding or a function of the costs involved in mitigating this by an appropriate abatement policy. Among the first studies on the link between flood event and house prices, Skantz and Strickland (1987) found out that home prices do not fall immediately after the flood and do not later rise either; these findings were consistent with rational and efficient markets, they concluded. In two other 1980s studies (cited by Chou and Shih, 2001), Donnelly estimated the capitalised perceived risk to be double compared to the capitalised actual risk, and Tobin and Newton concluded that land values decrease after flood event, similarly as after an earthquake.

Chou and Shih themselves studied the flood risk in 13 cities in Taipei Metropolis, Taiwan. According to their findings floods do not have obvious impact on house prices, but their evidence too showed that the impact of risk perception is larger than the actual risk measured as frequency of event $\mathrm{x}$ consequence (i.e. submerged area in ha). Furthermore, self-risk (floods, where the respondent in question resides) is larger than public perception of risks (in the other 12 cities). Finally, they concluded that people are unwilling to immigrate to the flood areas, which has consequences for prices.

Surprisingly, studies of flooding from the European context are rare. Eves and Brown (2002) however provide a thorough survey of flood related value effects. The background is a recent increase in flood liable residential areas and in flood damage in previously recognised areas; security risk for financial institutions; reluctance for insurance companies to insure properties in the affected areas; and government flood mitigation. Apparently, 10\% of the population in England and Wales are directly affected, which causes real and perceived health effects, physical damage, and disruption to trade, transport and services.

Eves and Brown reported their results in two stages. First, it was concluded that the proximity to a river may bring a premium of $10 \%$ or more, a discount of $10 \%$ or more, or an in between price effect depending on the flood potential of the area. Second, the impact of the flooding of $2000 / 2001$ on property prices (discount) was reported to be $0-20 \%$, again depending on the area, and a subdivision of the areas surveyed by Eves and Brown indicated that even greater magnitude may be possible. Notably, 10 of the 34 towns had a discount of less than $5 \%$. The results also showed that flood defenses bring a price increase in flood prone areas. It was also noted that the purchaser is not likely to consider flood affection as well as insurers, Charted Surveyors, and financers. A final observation was that this seasonal phenomenon depends on the development of the next 5-10 years.

Eves (2002) studied the long term processes related to the problem in Sydney, Australia. The idea was to identify areas that are potentially liable to flooding, using planning schemes (the buyers may be uninformed about the risk). Using house sales data on detached single-family and low rise medium density residential complexes from flood-prone vs. flood-free areas over a 17 years interval, he found that the price difference was minor 1984-87, but increased 
towards 1991. Since 11 floods were recorded after 1991, the difference has been decreasing, the peak being a $22.4 \%$ difference in 1991; the low being a $5.9 \%$ difference between the comparable areas in 1986. The risk was concluded to be similar for both property types.

For floodplain controls, Holway and Burby (1990) estimated the losses of actual floods experienced; price premium of flood control structure; loss for elevation requirements; and loss for prohibitions on development. The data comprised a cross-section of 100 years floodplains in the US (i.e. areas with a $1 \%$ possibility to be flooded in any year.) In the study the four effects were measured and reported separately, but for our purpose we summarise them to a total loss due to floods worth $\$ 1126$ (18\% of mean value).

For flood zone situation, Harrison et al. (2001) conducted a valuation of homes located within 100 -year flood plains, using a dataset of ca. 30,000 property transactions from Alachua County, Florida. Their results show that comparable homes within a flood zone sell on average for less than homes located outside flood zones.

Cordes and Yezer (1998), and Cordes et al. (2001) studied the effects of shore-protection efforts on real estate development, using a repeat-sale house price index of price appreciation rates to the water's edge. They too found no significant evidence that such efforts have caused additional beachfront development in Florida.

Campana and Tucci (2001) predicted floods from urban development scenarios, that is the other way of causality than in the studies reviewed above. According to the results, the proposed master plan will increase the peak flow by $25-30 \%$, but this effect can be alleviated by building measures such as bridges and increasing permeable areas. (See also Wernstedt and Hersh 2001, who predicted the potential flood disasters based on a model of El NinoSouthern Oscillation cycle.)

What do these results show? Although we do not attempt to dis-aggregate the few results by specific type of effect, nor by specific type of water body, similarly as with the positive amenity impact studies reviewed above, there is certainly a rationale for aggregation. Based on the few studies where an effect is quantified in a reliable way, we conclude that the (negative) impact of a flood event (or positive impact of flood abatement) on property prices is in the range $0-22 \%$. For drought, we estimate the effect to be half of this range, at the most.

This may now be deducted from the estimates reported in the previous section, if preferred. However, to include such a cost element in the calculation is not always justified. While flooding and (to a lesser extent) drought remain global issues, it will be difficult to transport the results outside the Anglo-Saxon physical and institutional context. For example, in the Netherlands the flood risk may be estimated zero for artificial lakes.

\section{Additional evidence using intensive methods}

We did not report results with a mere sign effect $(+/-)$ in the previous two sections as we aimed at a more detailed level of analysis. All these studies followed an analytic/quantitative approach, with the aim of assessment of quality; at best, they paid lip-service to the lifestyle factor. However, a more explicitly behavioural-cultural examination of actors and processes may be a useful approach, if the aim is to look for more latent effects than the effects observed in sections 3 and 4 . 
Two case-studies, both from Metropolitan Helsinki, Finland, deal with the culture of residential areas. Uuskallio (2001) concluded that ornaments, in their various forms, were important as a determinant of the discriminatory power of environmental values for the coastal neighbourhoods of the city core. Päivänen (1997) in turn compared two adjacent neighbourhoods situated on the coast of Espoo (west of Helsinki); these had similar physical features, regarding the proximity to the seashore. The sea identity was present in street-names, and the shore amenity was an element of the public space and also of natural space. Given the same physical amenities related to water, status had a discriminatory role: only for the upmarket area (Haukilahti) the "reasonable proximity to the sea" was, together with proximity to 'greenery', a determinant of relative attractiveness that the estate agents used in their marketing strategy; for the lower market segment (Matinkylä) the relevant characteristic was 'affordability'. In these two studies prices were shown in relation to quality, some of which is undoubtedly related to seaside coast proximity. While these ideas are not easy to make operational, these studies show that managers and other experts might know water and coastal related factors better than the consumer.

When treating the water element in a development setting, two recent studies are worth mentioning. Bassett et al. (2002) studied waterfront regeneration using an urban regime and governance approach; and Rogers et al. (2002) analysed water as an economic good within the institutional analysis/economics framework.

We can note that this broad cluster of theoretically informed approaches comprise a more qualitative standpoint to locational attractiveness than those reported in sections 3 and 4 . Here we emphasise processes, and we may tie the discussion to certain well-known propositions from social theory ${ }^{16}$.

\section{Summary and discussion of results}

The conceptual side of the problem formulation is relatively clear, but how to understand, compare, and combine the evidence across many functional, temporal and geographical contexts? The first problem to solve is to find the most convenient units for the comparison:

- for the majority of the studies the following applies: shadow price $=$ the amenity benefit the costs arising from negative externalities; if actual prices or costs are involved, they are used similarly, and as commensurate quantities with the shadow price calculations;

- in stated WTP estimates where no property value aspect is involved, we use the (annual) income as a basis for comparison ${ }^{17}$;

- in stated rank and ratio (i.e. multidimensional value) estimates, we use percentages as the basis for comparison.

Second, do we have to use a composite measure only, or is it possible to partition the results with type of water effect, and across contexts: use, time, place and location type,

\footnotetext{
${ }^{16}$ Ulrich Beck (value rotation and fashion), Pierre Bourdieu (specific life-styles and distinction), Thorstein Veblen (scarcity value and market disequilibrium), Yi-Fu Tuan and G. Bachelard (topofilia), or Patsy Healey (the agency-structure -based land development model), to name but a few.

${ }^{17}$ We may conclude that by multiplying the income by a factor (usually in the range of 3-5) we will obtain a measure that is comparable with annual or discounted housing expenditures, but that we leave open, to avoid further error margins.
} 
household/occupant segment and so forth? The body of water matters: in all studies, the sea is more desired than the lake, which is more desired than other, smaller, and less free bodies of water. Interestingly, the order of such water bodies is not uniform across studies: wetlands and marshes may be either less or more preferred than rivers and waterways (cf. Mahan et al., 2000; Ryan, 1998). Also the relevant effect to base the comparison on matters: we may distinguish between water quality, water/shore proximity, water/shore view, and water size. Furthermore, the suitable unit for the water proximity factor is related to the size and type of the water body in question.

Third, is it in all cases possible to both quantify and dis-aggregate the results as proposed above? No, unfortunately not. Inevitably a variety of miscellaneous studies will remain. Either these studies do not report magnitudes, or then they do so, but the results do not 'fit in', as there is something different in the context or framing of questions. The same goes for the dis-aggregation aspect: most studies are unfortunately carried out on an aggregate level, and then it is not feasible to reserve a discussion for various subpopulation specific results. We hope both of these problems will be overcome in future research, as standards develop across research communities.

Based on the literature, we report the composite effect for water quality, proximity and view as follows: the range for price premium is up to ca $60 \%$ for seaside property, $25 \%$ for lakeside property, and up to $40 \%$ for a variety of other inland water bodies. Furthermore, we conclude that the stated WTP for a water related improvement is very marginal overall, but that locations in the vicinity to water bodies are considered attractive choices to at least a certain proportion of the housing consumers, when compared to other locations. Also the size of the lake or river may have a positive effect, especially for recreational property. We also estimate the net effect related to on-site development restrictions of a coastal area: the effect on property value varies between a $21.5 \%$ positive amenity benefit (generated by the factors above), and a $14.5 \%$ negative opportunity cost.

So the amenity effect related to presence of water was found important for choice, attractiveness and price levels. However, the various conditional factors caused complex relationships across the studies reviewed. One such factor is the negative impact of flooding a very localised effect. That was quantified separately as up to $22 \%$, and may be deducted from the figures reported above. Then we obtain the following figures for the net effect of the price premium: $-22 \%$ to $+38 \%$ for seaside property, : $-22 \%$ to $+3 \%$, for lakeside property, and $-22 \%$ to $+18 \%$ for a variety of other inland water bodies.

To some extent we managed to quantify, and at least identify, the positive or negative effects of amenities and other factors, on the value and choice of locations by the water. Our findings show that the presence of water has a real value that is highly dependent on geographical area and type of land use. Based on the sixty studies with quantifiable conclusion, and another 2030 more studies with some relevance in relation to our topic that were reviewed, we may now conclude that for the attractiveness potential of a site the environmental externalities play a large role in two ways: I. Amenity/proximity - usually positive; II. Natural hazards: flood and drought-negative.

However, many questions remain open. In particular, we wish to stress, that the results are far from fully comparable, because different methods have been used in different contexts. We can predict that a voluntarist model of housing choice model does not work, if there are substantial constraints that generate extra cost related to a scarcity/monopoly value. When 
modelling housing claims spatially, such costs to overcome conflict and scarcity situations may arise, if all land uses are to be covered. Especially true this is for a country such as the Netherlands, where housing consumers have widely diversified preferences on one hand (bringing non-monetary benefits), and the housing markets are very severely constrained on the other hand (bringing costs related to scarcity value). This calls for a serious discussion on area assessment beyond the standard economic value assumptions.

\section{REFERENCES}

Acharya G. and Bennett L.L. (2001) Valuing Open Space and Land-Use Patterns in Urban Watersheds. Journal of Real Estate Finance and Economics, 22 (2/3): 221-237.

Balchin P. and Kieve J. (1977) Urban Land Economics, London: Macmillan.

Bassett K., Griffiths R. and Smith I. (2002) Testing Governance: Partnerships, Planning and Conflict in waterfront Regeneration. Urban Studies, 39 (10): 1757-1775.

Bastian C.T., McLeod D.M., Germino M.J., Reiners W.A. and Blasko B.J. (2002) Environmental amenities and agricultural land values: a hedonic model using geographic information systems data. Ecological Economics, 40: $337-349$

Bender A., Din A., Favarger P., Hoesli M. and Laakso J. (1997) An Analysis of Perceptions Concerning the Environmental Quality of Housing in Geneva. Urban Studies, 34 (3): 503-513.

Bennett L.L., Acharya G., Silva G. and Mendelsohn R. (1998) Valuing Open Space and Land Use Chaos in Urban Watersheds: An Hedonic Property Value Analysis. Paper prepared for the World Congress of Environmental and Resource Economists, Venice, 25-27 June.

Benson E.D., Hansen J.L., Schwartz A.L.:Jr. and Smersh G.T. (1998) Pricing Residential Amenities: The Value of a View. Journal of Real Estate Finance and Economics, 16 (1): 55-73.

Boyle M.A. and Kiel K. A. (2001) A Survey of House Price Hedonic Studies of the Impact of Environmental Externalities. Journal of Real Estate Literature, 9 (2): 117-144.

Boyle K.J. and Taylor L.O. (2001) Does the Measurement of Property and Structural Characteristics Affect Estimated Implicit Prices for Environmental Amenities in a Hedonic Model. Journal of Real Estate Finance and Economics, 22 (2/3): 303-381.

Campana N.A. and Tucci C.E.M. (2001) Predicting floods from urban development scenarios: case study of the Dilúvio Basin, Porto Alegre, Brazil. Urban Water, 3: 113-124.

Choe K., Whittington D. and Lauria D.T. (1996) The Economic Benefits of Surface Water Quality Improvements in Developing Countries: A Case Study of Davao, Philippines. Land Economics, 72 (4): 519-37.

Chou S.H. and Shih H.C. (2001) Impact Assessment of Flood Risk on Residential Property Market in Taipei Metropolis. Paper presented at the ERES Conference, Alicante, Spain, June 26-29.

Cordes J.J., Gatzlaff D.H. and Yezer A.M. (2001) To the Water's Edge, and Beyond: Effects of Shore Protection Projects on Beach development. Journal of Real Estate Finance and Economics, 22 (2/3): 287-302.

Cordes J.J and Yezer A.M. (1998) In Harm's Way: Does Federal Spending on Beach Enhancement and Protection Induce Excessive Development in Coastal Areas? Land Economics, 74 (1): 128-45.

Dale-Johnson D. and Yim H.K. (1990) Coastal Development Moratoria and Housing Prices. Journal of Real Estate Finance and Economics, 3: 165-184.

Del Saz-Salazar S. and Garcia-Menendez L. (2001) Redeveloping Dockland Areas for Recreation Purposes: A Contingent Valuation Study. Conference paper. ERES 2001 conference, Alicante, Spain. 
Earnhart D. (2001) Combining Revealed and Stated Preference Methods to Value Environmental Amenities at residential Locations. Land Economics, 77 (1): 12-29.

Evans A.W. (1983) The Determination of the Price of Land. Urban Studies, 20, 119-129.

Eves C. (2002) The long-term impact of flooding on residential property values. Property Management, 20 (4): 214-227.

Eves C. and Brown S. (2002) The Impact of Flooding on Residential Property Values in England. Paper presented at the 9th ERES conference, Glasgow, Scotland, June 4-7.

Faux J. and Perry G.M. (1999) Estimating Irrigation Water Value Using Hedonic Price Analysis: A Case Study in Malheur County, Oregon. Land Economics, 75 (3): 440-452.

Feenberg D. and Mills E.S. (1980) Measuring the Benefits of Water Pollution Abatement. Studies in urban economics. New York: Academic Press.

Fraser R. and Spencer G. (1998) The Value of an Ocean View: an Example of Hedonic Property Amenity Valuation. Australian Geographical Studies, 36 (1): 94-98.

Gartner W.C. and Chappelle D.E. (1996) The influence of natural resource characteristics on property value: a case study. Journal of Travel Research, 35 (1): 64-71

Geoghegan J., Wainger L.A. and Bockstael N.E. (1997) Spatial landscape indices in a hedonic framework: an ecological economics analysis using GIS. Ecological Economics, 23: 251-264.

Harrison D.M., Smersh G. and Schwartz A.L:Jr. (2001) Environmental Determinants of Housing Prices: The Impact of Flood Zone Status. Journal of Real Estate Research, 21 (1/2): 3-20.

Heins S. (2002) Rurale woonmilieus in stad en land. Plattelandsbeelden, vraag naar en aanbod van rurale woonmilieus. (Doctoral dissertation, in Dutch.) Utrecht University and Eburon.

Holway J. M. and Burby R. J. (1990) The Effects of Floodplain Development Controls on Residential Land Values. Land Economics, 66 (3): 259-271.

Kalbro T. (1994) Vinstfördelning vid genomförande av detaljplaner (in Swedish). In Viitanen K, Santala J. and Mella J. (eds): Ympäristö ja kiinteistöt. Maanmittaustieteiden päivät 24.-25.11.1994 (in Finnish), 181-192. Maanmittaustieteiden Seuran julkaisu n:o 31. Helsinki 1994.

Kauko T. (2002) Spatial housing market structure of urban areas: Comparison between evidence from Helsinki and Amsterdam. Paper presented at the ENHR workshops, Vienna, Austria, July 1-5.

Krausse G.H. (1995) Tourism and waterfront renewal: assessing residential perception in Newport, Rhode Island, USA. Ocean \& Coastal Management, 26 (3): 179-203.

Kyllönen L. and Räty T. (2000) Asuntojen hinta-laatusuhde Joensuussa, semiparametrinen estimointi (in Finnish). VATT-tutkimuksia 67.

Laakso S. (1992) Kotitalouksien sijoittuminen kaupunkitalousalueella (in Finnish). VATT- tutkimuksia 10. 155 pgs.

Laakso S. (1997) Urban Housing Prices and the Demand for Housing Characteristics. The Research Institute of the Finnish Economy (ETLA) A 27, Helsinki.

Lake I.R.. Lovett A.A., Bateman I.J. and Langford I.H. (1998) Modelling environmental influences on property prices in an urban environment. Computers, Environment and Urban Systems, Vol. 22, No. 2, 121-136.

Li M.M. and Brown H.J. (1980) Micro-Neighborhood Externalities and Hedonic Housing Prices. Land Economics, Vol. 56, No. 2, May, 125-141. 
Lovell S.J. and Sunding D.K. (2001) Voluntary Development Restrictions and the Cost of Habitat Conservation. Real Estate Economics, 29 (2): 191-206.

Luttik J. (2000) The value of trees, water and open space as reflected by house prices in the Netherlands. Landscape and Urban Planning, 48: 161-167.

Lynne G.D., Shonkwiler J.S. and Wilson M.E. (1991) Water Permitting Behavior under the 1972 Florida Water Resources Act. Land Economics, 67 (3): 340-51.

Magat W., Huber J., and Viscusi W.K. (2000) An Iterative Choice Approach to Valuing Clean Lakes, Rivers, and Streams. Journal of Risk and Uncertainty, 21(1): 7-43.

Mahan B.L., Polasky S. and Adams R.M. (2000) Valuing Urban Wetlands: A Property Approach. Land Economics, 76 (1): 100-113.

Mooney S. and Eisgruber L. M. (2001) The Influence of Riparian Protection Measures on Residential Property Values: The Case of the Oregon Plan for Salmon and Watersheds. Journal of Real Estate Finance and Economics, 22:2/3, 273-286.

Mäntymaa E. (1993) Preferenssien paljastamisesta contingent valuation -menetelmällä (in Finnish). Kansantaloudellinen aikakauskirja, 89:2, 213-221.

Nevalainen R., Staffans A. and Vuorela P. (1990) Asumisen laadun arviointi ja tutkiminen. (Evaluating and studying the quality of housing, in Finnish.) YTK B 60, Helsinki.

Orford S. (1999) Valuing the built environment - GIS and house price analysis. Ashgate, UK.

Orford S. (2002) Valuing locational externalities: a GIS and multilevel modelling approach. Environment and Planning B: Planning and Design, 29: 105-127.

Parsons G.R. and Wu Y. (1991) The Opportunity Cost of Coastal Land-Use Controls: An Empirical Analysis. Land Economics, 67 (3): 308-16.

Peltola R. (1998) Ranta-alueen arvo (in Finnish). Maanmittauslaitoksen julkaisuja nro 86; Kiinteistötietokeskus, Helsinki.

Poor P.J., Boyle K.J., Taylor L.O. and Bouchard R. (2001) Objective versus Subjective Measures of Water Clarity in Hedonic Property Value Models. Land Economics, 77 (4): 482-493.

Priemus H. (1998) Contradictions between Dutch housing policy and spatial planning. Tijdschrift voor Economische en Sociale Geografie, Vol. 89, No. 1, 31-43.

Päivänen J. (1997) Espoon eteläranta asuntomarkkinoilla (The South Coast of Espoo as a real estate product, in Finnish). In Ilmone, M., Lankinen M., Lehtonen H., Maury J., Päivänen J.: Mitä osoite osoittaa? Asuinalueiden erilaistuminen Helsingin seudulla. (How do you address yourself? Spatial differentiation in the Helsinki Region.) Pääkaupunkiseudun julkaisusarja B 1997:2, 107-128.

Ready R.C., Berger M.C. and Blomquist G.C. (1997) Measuring amenity benefits from farmland: hedonic pricing vs. contingent valuation. Growth and Change, Fall/97.

Rinehart J.R. and Pompe J.J. (1994) Adjusting the Market Value of coastal Property for Beach Quality. The Appraisal Journal, October, vol. LXII, No. 4; 604-608.

Rogers P., de Silva R. and Bhatia R. (2002) Water is an economic good: How to use prices to promote equity, efficiency, and sustainability. Water Policy, 4: 1-17.

Rush R. and Bruggink T.H. (2000) The value of ocean proximity on barrier island houses. The Appraisal Journal, 62 (1): 142-150. 
Ryan R.L. (1998) Local perceptions and values for a midwestern river corridor. Landscape and Urban Planning, 42: $225-237$.

Schalken F. (2002) De aqua-yup in opmars? Een geografische zoektocht naar de belangstelling van huishoudens voor het wonen op water in Nederland. (Master's Thesis, in Dutch.) Utrecht University.

Shilling J.D., Sirmans C.F. and Benjamin J.D. (1989) Flood Insurance, Wealth Redistribution, and Urban Property Values. Journal of Urban Economics, 26: 43-53.

Shultz S.D. and King D.A. (2001) The Use of Census Data for Hedonic Price Estimates of Open-Space Amenities and Land Use. Journal of Real Estate Finance and Economics, 22 (2/3): 239-252.

Skantz T.R. and Strickland T.H. (1987) House Prices and a Flood Event: An Empirical Investigation of Market Efficiency. Journal of Real Estate Research, 2 (2): 75-83.

Smith V.K. (1993) Nonmarket Valuation of Environmental resources: An Interpretive Appraisal. Land Economics, 69 (1): 1-26.

Spalatro F. and Provencher B. (2001) An Analysis of Minimum Frontage Zoning to Preserve Lakefront Amenities. Land Economics, 77 (4): 469-481.

Timmermans H., Molin E. and van Noortwijk L. (1994) Housing choice processes: stated versus revealed modelling approaches. Netherlands Journal of Housing and the Built Environment, 9 (3): 215-227.

Tyrväinen L. (1997) The amenity value of the urban forest: an application of the hedonic pricing method. Landscape and Urban Planning, 37: 211-222.

Uuskallio, I. (2001) Arvostetut asuinsijat. Asuntoalueiden arvostuksen sosiokulttuurinen analyysi 1900-luvun Helsingissä ja Tehtaankadulta etelään (In Finnish). City of Helsinki Urban Facts Research series 2001:8.

Van Kooten G.C. (1993) Bioeconomic Evaluation of Government Agricultural Programs on Wetlands Conversion. Land Economics, 69 (1):27-38.

Viitanen K. (2002) Professor of Real Estate, Helsinki University of Technology, Discussion, 10-10-2002, Delft, The Netherlands.

Wernstedt K. and Hersh R. (2001) When ENSO Reigns, it Pours: Climate Forecasts in Flood Planning. Discussion Paper 01-56, Resources for the Future. Washington D.C., US. (Also published at www.rff.org.)

Wilhelmsson M. (2002) Spatial Models in Real Estate Economics. Housing, Theory and Society, 19: 92-101.

Willis K.G. and Garrod G.D. (1993) Not from experience: a comparison of experts' opinions and hedonic price estimates of the incremental value of property attributable to an environmental feature. Journal of Property Research, 10, 193-216.

Wolverton M.L. (1997) Empirical study of the relationship between residential lot price, size and view. Journal of Property Valuation and Investment, 15:1, 48-57. 
APPENDIX 1: The presence of water quantified in amenity/proximity impact studies, from various contexts and following various approaches

\begin{tabular}{|c|c|c|c|}
\hline Who? When? Where? & $\begin{array}{l}\text { Research design: method, data set, market } \\
\text { segment etc. }\end{array}$ & \begin{tabular}{|l|} 
Functional \\
specification? \\
(linear OLS \\
presumed, unless a \\
transformation is \\
mentioned) \\
\end{tabular} & Basic finding regarding water amenity/proximity \\
\hline Li \& Brown (1980) & $\begin{array}{l}\text { Hedonic study; Boston, MA, suburban area; } \\
\text { house prices and prices/room, } 781 \text { obs. 1971, } \\
\text { census-tract level and micro-level } \\
\text { neighbourhood; proximity variables }\end{array}$ & & $\begin{array}{l}\text { Net effects of several local externalities; Price } \mathrm{R}^{2}: .79-81 \text {; Price/room } \mathrm{R}^{2}: .67 \text {; closeness to } \\
\text { the ocean and rivers are highly valued: } 10 \mathrm{~m} \text {. closer }=>\$ 1000(3 \%) \text { more price, when } \\
\text { mean value is } \$ 30,000\end{array}$ \\
\hline $\begin{array}{l}\text { David (1968, cited in } \\
\text { Boyle \& Kiel 2001) }\end{array}$ & $\begin{array}{l}\text { Hedonic study 1952-62; land value in relation } \\
\text { to } 3 \text { categories of water quality based on } \\
\text { opinions of government officials in } 60 \text { artificial } \\
\text { Wisconsin lakes }\end{array}$ & & Coefficients for water quality have correct sign (+); mostly significant \\
\hline $\begin{array}{l}\text { Epp \& Al-Ani: } \\
\text { Pennsylvania (1979, } \\
\text { cited in Boyle \& Kiel } \\
\text { 2001) }\end{array}$ & $\begin{array}{l}\text { Hedonic study 1969-76; rural, non-farm } \\
\text { communities; variables for water } \mathrm{pH} \text { in } \\
\text { streams; perceived water quality and also flood } \\
\text { hazard }\end{array}$ & & $\begin{array}{l}\text { Water quality found to have a significant effect on value, using both measurements: one } \\
\text { point increase in } \mathrm{pH}=>5.9 \% \text { increase in mean sales price; water quality has an interaction } \\
\text { effect with population growth }\end{array}$ \\
\hline $\begin{array}{l}\text { Young: Lake } \\
\text { Champlain, Vermont } \\
\text { (1984, cited in Boyle } \\
\text { \& Kiel 2001) }\end{array}$ & $\begin{array}{l}\text { Hedonic study; effect of perceived water } \\
\text { quality on homes; dummy variable for location } \\
\text { in the vicinity of a bay, indicated a polluted } \\
\text { location; also rating of water quality by local } \\
\text { officials }\end{array}$ & & Location within the polluted bay reduced the value by an average of $20 \%(\$ 5,000)$ \\
\hline $\begin{array}{l}\text { Steinnes: Minnesota } \\
\text { (1992, cited in Boyle } \\
\text { \& Kiel 2001) }\end{array}$ & $\begin{array}{l}\text { Hedonic study; secchi disk readings (number of } \\
\text { feet below the surface that a disk can be } \\
\text { observed) and appraisal data on leased lots } \\
\text { along } 53 \text { lakes }\end{array}$ & & $\begin{array}{l}1 \text { foot improvement in clarity increases sales price by } \$ 206-240 \text { (we estimate: below } 1 \% \text { of } \\
\text { the price); lake size, depth and accessibility were not significant }\end{array}$ \\
\hline $\begin{array}{l}\text { Mendelsohn, } \\
\text { Hellerstein, } \\
\text { Huguenin, Unsworth } \\
\text { and Brazee (1992, } \\
\text { cited in Boyle \& Kiel } \\
\text { 2001) }\end{array}$ & $\begin{array}{l}\text { Hedonic study; panel data } 1969-88 \text { to estimate } \\
\text { the impact of PCB pollution in the New } \\
\text { Bedford, Massachusetts harbour; dummy } \\
\text { variables for sales after pollution event, also } \\
\text { interaction between event and locational } \\
\text { proximity dummies }\end{array}$ & & $\begin{array}{l}\text { Homes whose nearest waters were affected by PCB were } \$ 7,000-10,000 \text { lower in value (we } \\
\text { estimate: } 20-30 \% \text { ) }\end{array}$ \\
\hline $\begin{array}{l}\text { Michael, Boyle and } \\
\text { Bouchard (1996, } \\
\text { cited in Boyle \& Kiel }\end{array}$ & $\begin{array}{l}\text { Hedonic study: } 34 \text { Maine lakes 1990-94; } \\
\text { Secchi readings of minimum clarity; } 1 \mathrm{~m} \text {. }\end{array}$ & & $\begin{array}{l}\text { Improvement in clarity increases sales prices by } \$ 11-200 \text { per front footage (assuming 0-50 } \\
\text { feet frontage, we estimate: max. } 7 \% \text { ); no additional water variables were included because } \\
\text { of correlation }\end{array}$ \\
\hline
\end{tabular}




\begin{tabular}{|c|c|c|c|}
\hline 2001) & & & \\
\hline $\begin{array}{l}\text { Leggett \& Bockstael } \\
\text { Anne Arundel } \\
\text { County, Maryland, } \\
\text { (2000, cited in Boyle } \\
\text { \& Kiel 2001) }\end{array}$ & $\begin{array}{l}\text { Hedonic study; house sales along the western } \\
\text { shore of the Chesapeake Bay } 1993-97 \\
\text { pollution variable: coliform concentration; } \\
\text { distances to various sources of pollution }\end{array}$ & & Increase of 100 fecal coliform count $/ 100 \mathrm{~mL}=>1.5 \%$ reduction in property value \\
\hline $\begin{array}{l}\text { Pollard, Chicago } \\
\text { (1982, cited in } \\
\text { Wolverton 1997) }\end{array}$ & $\begin{array}{l}\text { Hedonic study on the view of Lake Michigan,; } \\
232 \text { apartments in } 154 \text { buildings }\end{array}$ & & $\begin{array}{l}\text { A view adds ca. } 7 \% \text { on rents; buildings with a view are } 1.77 \text { times taller than buildings } \\
\text { without a view }\end{array}$ \\
\hline $\begin{array}{l}\text { Choe, Whittington \& } \\
\text { Lauria (1996); } \\
\text { Davao, Philippines }\end{array}$ & $\begin{array}{l}\text { Proximity and access to better quality water } \\
\text { among people; CV and travel cost methods }\end{array}$ & & $\begin{array}{l}\text { CV and travel cost estimates were close to each other and quite low; hence a low WTP } \\
\text { among these residents to pay for improved water quality (we do not consider this result in a } \\
\text { quantitative sense) }\end{array}$ \\
\hline $\begin{array}{l}\text { Laakso }(1992 ; 1997) \\
\text { Helsinki }\end{array}$ & $\begin{array}{l}\text { Hedonic study on house prices; location in the } \\
\text { vicinity of a coast one variable in a total } \\
\text { housing market model; sample: city: } 18820 \\
\text { observations } 1980,1985,1989 \text {; metropolitan } \\
\text { area: } 17290 \text { obs. } 1993\end{array}$ & $\begin{array}{l}\text { Semi-log, } \\
\text { logarithmic } \\
\text { (+splines) } \\
\text { regression; also } \\
\text { hedonic demand } \\
\text { equations (5 } \\
\text { housing } \\
\text { characteristics) } \\
\end{array}$ & $\begin{array}{l}\text { Location by the sea }=>25-30 \% \text { premium; m.a./adj. } \mathrm{R}^{2}: 76-87 \text {; city/adj. } \mathrm{R}^{2}: 83-92 \text {; } \\
\text { demand/adj. } \mathrm{R}^{2}: 6-27 \text {; in the outer segment, where the coast is not as accessible as in the } \\
\text { inner city segment, the distance decay effect of coast is stronger; valuation of the coast has } \\
\text { increased with time as accessibility has decreased?) }\end{array}$ \\
\hline $\begin{array}{l}\text { Mäntymaa (1993), } \\
\text { Oulujärvi-lake, } \\
\text { Finland }\end{array}$ & $\begin{array}{l}\text { Assessment of water quality improvement (1) } \\
\text { from 'satisfactory' to 'good' level; (2) do not } \\
\text { fall from to 'satisfactory' to 'insufficient'; 5- } \\
\text { point scale; contingency valuation; the } \\
\text { respondents were owners of parcels }(\mathrm{N}=210)\end{array}$ & & $\begin{array}{l}\text { Annual payments: for (1) FIM 546; for (2) FIM 791; (we estimate: this is not more than } \\
1 \% \text { of annual income); recreational fishers and owners of season/2nd home give } \\
\text { substantially higher WTP (1: 690; } 2: 1027) \text { than forest owners }(378 ; 406) \text { (problems: what } \\
\text { about persons who belong to both groups); Estimates are significant and logical; R-sq. } 0.25 \text { - } \\
.30 \text { methodological evaluation positive as well; higher income increases WTP } 0.1 \% 18-29 \\
\text { years old pay FIM } 647 \text { more than others. }\end{array}$ \\
\hline $\begin{array}{l}\text { Willis \& Garrod } \\
\text { (1993); London, } \\
\text { midlands and other } \\
\text { UK area }\end{array}$ & $\begin{array}{l}\text { Proximity or location at canal or inland } \\
\text { waterways }(\mathrm{N}=43) \text {; Hedonic (jackknife) } \\
\text { regression vs. contingent valuation }\end{array}$ & & $\begin{array}{l}\text { The significant results in both models: price increases with hedonic analysis: } \\
\text { frontage/London: } 2 \% \text {; /Midlands: } 6 \% \text {; proximity/London: } 1 \% \text {; : price increases with } \\
\text { contingent valuation: frontage/London: } 24 \% \text {; /Midlands: } 9 \% \text {; proximity/London: } 12 \%\end{array}$ \\
\hline $\begin{array}{l}\text { Geoghegan, Wainger } \\
\text { and Bockstael (1997); } \\
\text { Chesapeake, } \\
\text { Watershed }\end{array}$ & $\begin{array}{l}\text { Hedonic price model using spatial landscape } \\
\text { indices with regard to a region within a } 30 \text {-mile } \\
\text { radius of Washington DC; waterfront } \\
\text { (wetlands/water) dummy as a control variable }\end{array}$ & $\begin{array}{l}\text { Logarithmic, also } \\
\text { quadratic }\end{array}$ & $\begin{array}{l}\text { Significant coefficient } 0.343 ; \text { (adj.-R-sq.: .492) } \\
\text { That means a } 40 \% \text { increase for waterfront location }\end{array}$ \\
\hline $\begin{array}{l}\text { Tyrväinen (1997), } \\
\text { Joensuu, Finland }\end{array}$ & $\begin{array}{l}\text { Hedonic study, apartment price data } 1984-86, \\
\text { the value of recreational amenities, in the area } \\
\text { of Lake Pyhäselkä; the typical feature is water; } \\
\text { control variable for water proximity }\end{array}$ & $\begin{array}{l}\text { Linear, (also } \\
\text { Semilog tried) }\end{array}$ & $\begin{array}{l}\text { Distance to watercourses (along streets/path) had significant coeff. : }-153.97 \text { (R-sq.: .66); if } \\
100 \mathrm{~m} \text {. away from the water; i.e. price/sqm. decreases FIM } 154=4 \% \text {; distance to nearest } \\
\text { beach was not significant }\end{array}$ \\
\hline
\end{tabular}




\begin{tabular}{|c|c|c|c|}
\hline $\begin{array}{l}\text { Priemus (1997), The } \\
\text { Netherlands }\end{array}$ & $\begin{array}{l}\text { Survey of VINEX candidates, ornamental } \\
\text { waters among } 13 \text { environmental attributes } \\
\text { defined as facilities in the immediate vicinity of } \\
\text { the dwelling, at a short distance from the } \\
\text { dwelling }\end{array}$ & & $\begin{array}{l}\text { Strength of the ornamental waters -variable is 'very important': ca } 30 \% \text { of respondents; it is } \\
\text { at least 'rather important': ca } 75 \% \text { of respondents }\end{array}$ \\
\hline $\begin{array}{l}\text { Benson, Hansen, } \\
\text { Schwartz Jr. \& } \\
\text { Smersh (1998) } \\
\text { Bellingham, } \\
\text { Washington (they } \\
\text { also cite hedonic } \\
\text { analyses on distance } \\
\text { to lakes (Darling } \\
\text { 1973; Brown \& } \\
\text { Pollakowski 1977; } \\
\text { Plattner \& Campbell } \\
\text { 1978) }\end{array}$ & $\begin{array}{l}\text { Hedonic study of 7,305 single-family house } \\
\text { sales 1984-94; GIS+ personal inspection of all } \\
\text { sites, seven categories of view (4 quality } \\
\text { categories for ocean view, lake frontage, lake } \\
\text { view without frontage; and mountain view); the } \\
\text { interaction between distance to the shore and } \\
\text { the quality of the view }\end{array}$ & $\begin{array}{l}\text { Box-Cox } \\
\text { transformation }\end{array}$ & $\begin{array}{l}\text { R-sq. :75-.79; price premiums: } 8 \% \text { for poor partial ocean view; } 18 \% \text { for lake view; } 29 \% \\
\text { for good partial ocean view; } 31 \% \text { for superior partial ocean view; } 60 \% \text { for an unobstructed } \\
\text { ocean view; the value of an ocean view rose in the late } 80 \text { s, a period of market upswing; } \\
\text { conclusions from the literature review: quality of lake view is not specified, and therefore it } \\
\text { is difficult to make comparisons across results reported in currency }\end{array}$ \\
\hline $\begin{array}{l}\text { Del Saz-Salazar \& } \\
\text { Garcia-Menendez } \\
\text { (2001), Castellón, } \\
\text { Spain, } 1998\end{array}$ & $\begin{array}{l}\text { Contingent valuation; the value of } \\
\text { environmental improvements derived from } \\
\text { developing port-areas for recreational purposes } \\
\text { (over three years) }\end{array}$ & Spike models & $\begin{array}{l}\text { WTP }=7475 \text { PTS/year (we estimate } 0.26 \% \text { of annual income; that is } 0.78 \% \text {, if payment all } \\
\text { three years are made in one year) is significantly correlated to income and age (negatively), } \\
\text { the expected use of the new recreational facilities, and subjective value given to the project }\end{array}$ \\
\hline $\begin{array}{l}\text { Dale-Johnson \& Yim } \\
\text { (1990) Los Angeles } \\
\text { County }\end{array}$ & $\begin{array}{l}\text { Coastal development moratoria; house sales, } \\
\text { 1970-78, 23,384 obs. (permit area 8,710; inland } \\
\text { area 14,674) prior/after event date (Jan. 1973) }\end{array}$ & $\begin{array}{l}5 \text { models, } \\
\text { dependent } \\
\text { variables: ratios of } \\
\text { the price series for } \\
\text { before/after the } \\
\text { event date) }\end{array}$ & $\begin{array}{l}\text { Net effect of development restrictions and amenity increase generated: } 6.8 \% \text { premium for } \\
\text { houses in impacted area; } 19.9 \% \text { premium as of the event date; }\end{array}$ \\
\hline $\begin{array}{l}\text { Spalatro \& } \\
\text { Provencher (2001), } \\
\text { Wisconsin. }\end{array}$ & $\begin{array}{l}\text { Provide a hedonics based assessment of } \\
\text { planning controls on property value; the } \\
\text { economic net cost or benefit of minimum } \\
\text { frontage zoning on lakefront property is a sum } \\
\text { of competing effects: amenity effect - } \\
\text { development effect }\end{array}$ & & $\begin{array}{l}\text { The positive amenity effect is the more substantial of the two hypothesised effects: the net } \\
\text { effect is a price increase of } 21.5 \%\end{array}$ \\
\hline $\begin{array}{l}\text { Parsons \& Wu } \\
\text { (1991); Chesapeake } \\
\text { Bay, US, 1986-2005 }\end{array}$ & $\begin{array}{l}\text { Hedonic model; the average annual losses due } \\
\text { to the opportunity cost of coastal land use } \\
\text { controls, random sample ( } \mathrm{n}=1435) \text { houses } \\
\text { within } 6 \text { miles from the coastline; lost } \\
\text { accessibility, view and/or frontage }\end{array}$ & $\begin{array}{l}\text { Linear, } \\
\text { logarithmic, Box- } \\
\text { Cox }\end{array}$ & $\begin{array}{l}\text { Depending on the scenario the total cost for the areas is } 1.2-19.1 \text { million dollars; per } \\
\text { house this is } \$ 835-13,310(0.9-14.5 \%) \text {. R-sq. .64-.79); that is the value of the water amenity } \\
\text { if the planning control was removed }\end{array}$ \\
\hline Orford $(1999 ; 2002):$ & Multi-level specifications (i.e. property-level, & models, first for & Proximity to river (property level) adds $£ 9000(20 \%)$, if situated within $50 \mathrm{~m}$ (1th buffer \\
\hline
\end{tabular}




\begin{tabular}{|c|c|c|c|}
\hline Cardiff, UK & $\begin{array}{l}\text { street-level, district-level, community-level) of } \\
\text { the hedonic model, house prices, proximity } \\
\text { variables, constructed as interval dummies, } \\
\text { based on measured distances to both positive } \\
\text { ones among other factors, rivers; } 4 \text { buffer zones } \\
\text { of } 50 \mathrm{~m} \text {. from the river }\end{array}$ & $\begin{array}{l}\text { more general } \\
\text { analysis and then } \\
\text { for valuation of } \\
\text { locational } \\
\text { externalities in a } \\
\text { part of the city. }\end{array}$ & zone) - no effect if situated further \\
\hline $\begin{array}{l}\text { Mahan, Polasky } \\
\text { \&Adams (2000), } \\
\text { Portland, Oregon }\end{array}$ & $\begin{array}{l}\text { two-stage hedonic WTP approach: residential } \\
\text { property ( } \mathrm{n}=14,485) \text {; size of and distance to } \\
\text { wetlands; four types used depending on the } \\
\text { amount of vegetation; control variables incl. } \\
\text { proximity of lakes rivers and streams. }\end{array}$ & $\begin{array}{l}\text { Logarithmic } \\
\text { (partially semi-log } \\
\text { ) }\end{array}$ & $\begin{array}{l}\text { Wetlands influence the property price differently than other amenities. The size of the } \\
\text { wetlands and its proximity matters, but not the type of wetlands; increasing the size of } \\
\text { nearest wetland one acre => \$24 increase in price }(0.02 \%) \text {; reducing the distance to nearest } \\
\text { wetland by } 1000 \text { feet }=>\$ 436(0.3 \%) \text {. Preference order: } 1 \text {. lakes, } 2 \text {. wetlands, 3. streams }\end{array}$ \\
\hline $\begin{array}{l}\text { Magat, Huber \& } \\
\text { Viscusi (2000); } \\
\text { Colorado and North } \\
\text { Carolina }\end{array}$ & $\begin{array}{l}\text { Regression analysis within an iterative choice } \\
\text { approach (related to conjoint analysis) to } \\
\text { valuing water quality, understood as a measure } \\
\text { of safety in terms of swimming, fishing and } \\
\text { boating in the lake or river.; choices expressed } \\
\text { in terms of region or policy changes; also for } \\
\text { different character of water change, use } \\
\text { dimensions, and non-use }\end{array}$ & & $\begin{array}{l}\text { Tradeoff rates across quality dimensions, as well as tradeoff rate between improved quality } \\
\text { and money; water quality is valued to } \$ 22.40 \text { per additional } \% \text { improvement }(0.06 \% \text { of } \\
\text { household income; hence for a } 15 \% \text { improvement in quality } 0.9 \%) \text {; water quality valuations } \\
\text { differ for aquatic environment, edible fish, and swimming; also for water that is cloudy, } \\
\text { smelly, or polluted by toxics; minorities in particular rely on monitorable water quality } \\
\text { attributes; }+\$ 9 \text {, if visited a lake/river in last } 12 \text { months; water quality improvement more } \\
\text { than twice as valuable for lakes than rivers }\end{array}$ \\
\hline $\begin{array}{l}\text { Luttik (2000) from } \\
\text { three different Dutch } \\
\text { localitites (Emmen, } \\
\text { Apeldoorn, Leiden) }\end{array}$ & $\begin{array}{l}\text { Hedonic study on the type of view; house sales } \\
\text { 1989-92; } 3000 \text { sites were visited; views to } \\
\text { lakes and canals that are connected to sizeable } \\
\text { lakes }\end{array}$ & & $\begin{array}{l}\text { Shadow prices for environmental attributes: 'garden facing water' up to } 28 \% \text {; 'pleasant } \\
\text { view overlooking lake' } 8-10 \% \text {; 'lake facing garden' } 11-12 \% \text {; 'lake in the vicinity' } 5-10 \% \text {; } \\
\text { 'view of canal 4-5\%' In particular, the study confirmed the expectation that the presence of } \\
\text { and proximity to water is an important factor in the housing price bundle => scarcity }\end{array}$ \\
\hline $\begin{array}{l}\text { Boyle \& Taylor } \\
\text { (2001) Maine }\end{array}$ & $\begin{array}{l}\text { Lake-water quality, measured with a Secchi } \\
\text { disk ( } 8 \text { inches in diameter) in the summer } \\
\text { months during the year of transaction 1990-95; } \\
\text { comparison between recorded tax-assessor data } \\
\text { and perceived/survey data ( } \mathrm{n}=\text { ca 300) from } \\
\text { purchasers of properties with frontage on } 34 \\
\text { freshwater lakes and ponds threatened by } \\
\text { organic enrichment, hedonic model partitioned } \\
\text { into four location specific market groups }\end{array}$ & & $\begin{array}{l}\text { Lake-water quality is found significant and the magnitudes are not different: impact varied } \\
\$ 2,000-8,000 \text { per meter of clarity depending on the segment }(2.4-8.2 \%) \text {; also the lake } \\
\text { surface area and whether or not the primary source of water is the lake were tried, although } \\
\text { not found significant in all segments nor for both data sources }\end{array}$ \\
\hline $\begin{array}{l}\text { Shultz \& King (2001) } \\
\text { Tucson, US } \\
\text { (they also cite Doss } \\
\text { \&Taff's hedonic } \\
\text { study on wetlands } \\
\text { and lakes, 1996) }\end{array}$ & $\begin{array}{l}\text { Hedonic study on value and capitalised } \\
\text { monthly rents ( } 1990 \text {, aggregated on block- } \\
\text { level), distance in mile/10 to two classes of } \\
\text { wild-life habitat/river; use of GIS and census } \\
\text { data from } 6,277 \text { blocks }\end{array}$ & $\begin{array}{l}\text { Inverse semilog } \\
(\mathrm{P}=\beta \text { lnd }) \text { for the } \\
\text { distance variables }\end{array}$ & $\begin{array}{l}\text { Models for different samples (R-sq. Adj.: .52-.55); proximity to open space amenities } \\
\text { (marginal value of locating } 160 . \mathrm{m} \text { closer to the habitat), two of them are to wildlife habitat } \\
\text { - rivers and streams that are often dry for most of the year: class I (more pristine and } \\
\text { biologically important) habitat has negative price influence (i.e. the longer the distance, the } \\
\text { higher the value) } \$ 76-108 \text { (we estimate for } 100 \mathrm{~m}: 0.04-0.06 \%) \text {; class II has positive price } \\
\text { influence } \$ 205-352(0.11-0.19 \%) \text {; the variable is very sensitive to reduced sample sizes }\end{array}$ \\
\hline
\end{tabular}




\begin{tabular}{|c|c|c|c|}
\hline $\begin{array}{l}\text { Schalken (2002) } 4 \\
\text { housing market areas } \\
\text { in different parts of } \\
\text { the Netherladns }\end{array}$ & $\begin{array}{l}\text { Water proximity as a specific determinant of } \\
\text { housing preferences, study based on } \\
\text { interviews: } n=340 \text { (known home location); } \\
\mathrm{n}=491 \text { in total }\end{array}$ & & $\begin{array}{l}\text { The resident characterised as 'aqua yup' also splits the attributes and evaluates them from } \\
\text { functional or status point of view; ranks: the three most preferred positive attributes: } 1 \text {. } \\
\text { view; } 2 \text {. peace and space; } 3 \text {. natural beauty; negative attributes similarly: } 1 \text {. lack of garden; } \\
\text { 2. dangerous for children; } 3 \text {. insects. } 34 \% \text { have a propensity to move to a house by the } \\
\text { water ( } 59 \text { were unsure); } 26 \% \text { would like to pay more ( } 38 \% \text { was unsure). }\end{array}$ \\
\hline $\begin{array}{l}\text { Heins (2002) } \\
\text { The Netherlands, } \\
\text { selected locations in } \\
\text { and outside Randstad }\end{array}$ & $\begin{array}{l}\text { Telephone interviews, and DPN on rural } \\
\text { housing preferences; water (lake and river) } \\
\text { proximity included }(\mathrm{n}=112)\end{array}$ & $\begin{array}{l}\text { Three types of } \\
\text { values associated } \\
\text { to the location } \\
\text { attributes: } \\
\text { absolute; those } \\
\text { with tradeoff } \\
\text { possibility; and } \\
\text { unproblematic, } \\
\text { when not included }\end{array}$ & $\begin{array}{l}39 \% \text { of the respondents found water in the vicinity important enough to require a tradeoff } \\
\text { with other attributes; compared to having a garden }(95 \%) \text {, for example, water preferences is } \\
\text { not particularly strong per se unless it is latent within other factors; altogether } 77 \% \text { listed } \\
\text { water as a determinant of location choice }\end{array}$ \\
\hline $\begin{array}{l}\text { Kauko (2002) } \\
\text { Metropolitan } \\
\text { Helsinki and } \\
\text { Amsterdam }\end{array}$ & $\begin{array}{l}\text { Helsinki: location in the vicinity of a coast (or } \\
\text { lake); same } 1993 \text { data as Laakso used (see } \\
\text { above); Amsterdam: location in the vicinity of } \\
\text { a coast /canal/river/lake/pond etc (aggregated } \\
\text { 1999); also situation by a canal (waterfront } \\
\text { location); individual data 1986-2002 }\end{array}$ & $\begin{array}{l}\text { Neural network } \\
\text { approach }\end{array}$ & $\begin{array}{l}\text { Helsinki: shoreline proximity brings a clear price premium for two segments defined by } \\
\text { location and house type; own estimation: } 12 \% \text {. } \\
\text { Also in Amsterdam the importance of presence of water is evident as a determinant of price } \\
\text { and lower area density, but not in a linear sense. Some overlap between presence of water / } \\
\text { no water and expensive/cheap areas was observable; canal frontage shows up sharply; in } \\
\text { some cases associated with expensive and/or spacious areas; for comparable houses, own } \\
\text { estimation: the canal frontage situation has a negative impact (17.5\%) on the total sales } \\
\text { price of the dwelling }\end{array}$ \\
\hline $\begin{array}{l}\text { Kyllönen \& Räty } \\
\text { (2000) Joensuu }\end{array}$ & $\begin{array}{l}\text { Partly non-parametric specification of the } \\
\text { hedonic model }(1985-97 ; \mathrm{n}=1712) \text {; two } \\
\text { parametric water variables: shore proximity } \\
\text { dummy if less than } 300 \mathrm{~m} \text {. from the shore of a } \\
\text { lake; shore view dummy, if }<300 \mathrm{~m} \text { to shore } \\
\text { and no buildings in between }\end{array}$ & $\begin{array}{l}\text { Spline functions } \\
\text { for two variables; } \\
\text { also models } \\
\text { partitioned by } \\
\text { price }\end{array}$ & $\begin{array}{l}\text { Shore view dummy: coeff. } 30852 \text { for earlier period }(-1993) \text {; } 33642 \text { for latter period }(-1994) \text {, } \\
\text { i.e. FIM } 31,000(25 \%) \text { and } 34,000(19 \%) \text {; shore proximity dummy insignificant } \\
\text { For the three price segments: the higher the price group, the share of observations } \\
\text { possessing a shore view is not significantly larger }\end{array}$ \\
\hline $\begin{array}{l}\text { Wilhelmsson (2002), } \\
\text { Stockholm, 2000- } \\
2001\end{array}$ & $\begin{array}{l}\text { Standard vs. spatially extended regression; sea } \\
\text { view (dummy 0/1) among the control variables } \\
(\mathrm{n}=1377)\end{array}$ & $\begin{array}{l}\text { Logarithmic OLS, } \\
\text { Spatial lag } \\
\text { (SAR)and error } \\
\text { models (SEM) } \\
\end{array}$ & $\begin{array}{l}\text { OLS: coeff. sea view: } 0.337 \text {; SAR: } 0.287 \text {; SEM: } 0.279 ; \text { (R-sq.adj: .66; .69; .69); SEM with } \\
\text { alternative weight matrixes: coeff. sea view: 0.224-0.278. WTP/sea view: with OLS: } \\
1,067,000 \text { SEK ( } 40 \% \text { of average sales price) ; with SEM: } 675,000 \text { SEK; }(26 \%)\end{array}$ \\
\hline $\begin{array}{l}\text { McLeod, Perth, } \\
\text { western Australia } \\
\text { (1984, cited in Fraser } \\
\& \text { Spencer 1998) }\end{array}$ & $\begin{array}{l}\text { Hedonic study, value of a river view, dummy } \\
\text { variable, house sales }\end{array}$ & & Price premium $28 \%$ \\
\hline $\begin{array}{l}\text { Fraser \& Spencer } \\
\text { (1998), western } \\
\text { Australia }\end{array}$ & $\begin{array}{l}\text { Hedonic study, ocean view for undeveloped } \\
\text { residential sites }(\mathrm{n}=114) \text {, scoring matrix } 0-10 \\
\text { based on the potential loss of view and degree }\end{array}$ & Linear, logarithmic & $\begin{array}{l}\text { The best ocean view increased the price } 25 \% \text {; a better view increased the price, but with a } \\
\text { diminishing rate (marginal utility) ; elevation not reported, distance not significant (R- } \\
\text { sq.adj.:0.79) }\end{array}$ \\
\hline
\end{tabular}




\begin{tabular}{|c|c|c|c|}
\hline & of panorama; also elevation; distance to ocean & & \\
\hline $\begin{array}{l}\text { Krausse, 1995, } \\
\text { Newport Rhode } \\
\text { Island }\end{array}$ & $\begin{array}{l}\text { Survey ( } 72 \text { questions) of } 160 \text { harbour residents, } \\
\text { the perception of tourism and redevelopment; } \\
\text { proximity and waterfront location }\end{array}$ & & $\begin{array}{l}83 \% \text { of the respondents wanted more access to water, but only 1-\% agreed that it should be } \\
\text { implemented via parks, marinas or housing projects; related consequences: parking, } \\
\text { housing supply, transformation of residents to commercial outlets. } 42 \% \text { agreed that } \\
\text { waterfront location increases property value (other attributes increase less). }\end{array}$ \\
\hline $\begin{array}{l}\text { Lansford \& Jones, } \\
\text { Highland Lakes, } \\
\text { Colorado river basin, } \\
\text { Texas (1995, cited in } \\
\text { Mooney \& Eisgruber } \\
\text { 2001) }\end{array}$ & Hedonic studies; residential property & & Scenic view increased the price by $8 \%$ (lake?) \\
\hline $\begin{array}{l}\text { Kulshreshtha \& } \\
\text { Gillies, Saskatoon, } \\
\text { Canada (1993, cited } \\
\text { in Mooney \& } \\
\text { Eisgruber 2001) }\end{array}$ & $\begin{array}{l}\text { Consumers WTP (hedonic)or house with a } \\
\text { river view }\end{array}$ & & Price increase found \\
\hline $\begin{array}{l}\text { Streiner \& Loomis, } \\
\text { 1996, cited in } \\
\text { Mooney \& Eisgruber } \\
(2001), \text { Colorado }\end{array}$ & Hedonic study & & $\begin{array}{l}\text { Property value increased } \$ 4,500 \text { - } \$ 19,000 \text { (we estimate } 3-14 \% \text { ) in areas with restored } \\
\text { urban streams. }\end{array}$ \\
\hline $\begin{array}{l}\text { Bender, Din, } \\
\text { Favarger, Hoesli \& J. } \\
\text { Laakso (1997) in } \\
\text { Geneva, Switzerland }\end{array}$ & $\begin{array}{l}\text { an AHP based approach for multidimensional } \\
\text { evaluation of perceptions concerning the } \\
\text { environmental quality; questionnaire to } 850 \\
\text { house owners, } 153 \text { completed answers; } \\
\text { environmental attributes; link to a GIS }\end{array}$ & $\begin{array}{l}\text { Additive model; } \\
\text { Multiplicative } \\
\text { scale } 1 . .8\end{array}$ & $\begin{array}{l}\text { A 'pure' preference modelling perspective - no price information was used; distance to } \\
\text { green areas (rivers, lake and green area) was found the most important attribute with a } \\
\text { weight of } 18 \% \text { (we assign, arbitrarily, the share of the water element in this to } 9-12 \% \text { ); in } \\
\text { Geneva there are not much variation in social dimensions, therefore the physical factors are } \\
\text { more pronounced }\end{array}$ \\
\hline $\begin{array}{l}\text { Gartner, Chappelle \& } \\
\text { Pages } \\
\text { (1996),Michigan }\end{array}$ & $\begin{array}{l}\text { Related to hedonic regression, but owners' own } \\
\text { estimates of value collected through survey } \\
\text { from 2,006 owners of recreational property } \\
(1967-77)\end{array}$ & & $\begin{array}{l}\text { Location at larger lakes increases the value per acre as follows: } 25-100 \text { and } 500+\text { acres: } \\
\$ 16,000 \text { (adding } 123 \% \text { to land value) for seasonal home (SH); } \$ 32,000(246 \% \text { to land } \\
\text { value) for permanent home (PH); } 100-500 \text { acres: } \$ 40,000(307 \%) \text { SH; } \$ 32,000(246 \%) \mathrm{PH} \text {. } \\
\text { Some water bodies are preferred over others; the omitted variable bias was recognised }\end{array}$ \\
\hline $\begin{array}{l}\text { Ready, Berger \& } \\
\text { Blomquist (1997) } \\
\text { Kentucky }\end{array}$ & $\begin{array}{l}\text { Hedonic regression }(n=3,414) \text {; coast dummy } \\
\text { for whether the county of residence touches an } \\
\text { ocean or a Great Lake (Control variable); }\end{array}$ & Logarithmic & $\begin{array}{l}\text { According to hedonic results coast location increases the logarithm of farmland price } 7.7 \% \\
(=\text { price increase } 8.0 \%) \text {, as measured in monthly housing expenditures; in monthly wage - } \\
0.19 \%(=-1.9 \%)\end{array}$ \\
\hline $\begin{array}{l}\text { Ryan (1998) River } \\
\text { Raisin Watershed, } \\
\text { Michigan }\end{array}$ & $\begin{array}{l}\text { Survey of } 120 \text { local rural property owners, on } \\
\text { their perceptions and values for a river } \\
\text { corridor; photos, written questions and } \\
\text { schematic diagrams, } 5 \text { point scale }\end{array}$ & $\begin{array}{l}\text { Non-metric factor } \\
\text { analysis }\end{array}$ & $\begin{array}{l}\text { River scenes were the highest in preference, overgrown stream scene the lowest preference; } \\
\text { distance to the river was related to the water quality problems; respondents opposed new } \\
\text { development in the area; residential owners preferred the natural landscapes over the } \\
\text { domesticated elements of the scenes compared to the farmers, who had a preference for less } \\
\text { natural landscapes; newer residents preferred the natural attributes of the river location } \\
\text { more than long-time residents; also problems were recognised: flooding (see app. } 2 \text { below) } \\
\text { and insects; river photo: } 3.88 \text {, if moved, would miss nearby water: } 4.25 \text {; riverfront water: }\end{array}$ \\
\hline
\end{tabular}




\begin{tabular}{|c|c|c|c|}
\hline & & & $\begin{array}{l}\text { 3.24; water quality: } 3.57 \text {; weights for natural areas > water attributes > woods, farms, built } \\
\text { areas. }\end{array}$ \\
\hline $\begin{array}{l}\text { Rush \& Bruggink } \\
\text { (2000) Long } \\
\text { Beach Island, New } \\
\text { Jersey (they also cite } \\
\text { Wertheim, P. Jividen, } \\
\text { J. Jividen, Chatterhee } \\
\text { and Capen: hedonic } \\
\text { study on the impact } \\
\text { of beach on property } \\
\text { value, 1992) }\end{array}$ & $\begin{array}{l}\text { Hedonic regression; value of ocean proximity } \\
\text { on barrier island houses }(\mathrm{n}=100) \text {; variables: } \\
\text { ocean or bay; frontage or distance measured in } \\
\text { houses; market prices and assessments }\end{array}$ & Semi-log & $\begin{array}{l}\text { A house with an ocean frontage of } 50 \text { feet (cf. mean } 11 \text { feet) is worth } \$ 431,000 \text {; a similar } \\
\text { house located } 11 \text { houses away from the ocean is worth } \$ 205,000 \text {; moving the house } 8 \\
\text { houses closer adds } \$ 61,000(30 \%) \text {; the magnitudes reported did not differ significantly } \\
\text { between the hedonic models based on transaction prices and assessments, coefficients: } \\
\text { bayfront: } 0.003 / 0.004(0.3-0.4 \%) \text {; oceanfront: } 0.004-7 / 0.006-9(0.4-0.9 \%) \text {; distance to bay: } \\
0.015 / 0.015(1.5 \%) \text {; distance to ocean: } 0.033 / 0.033(3.4 \%) \text {. }\end{array}$ \\
\hline $\begin{array}{l}\text { Mooney \& Eisgruber } \\
\text { (2001) Mohawk } \\
\text { watershed, western } \\
\text { Oregon. }\end{array}$ & $\begin{array}{l}\text { A hedonic model of property values; the } \\
\text { influence of a strip of vegetation that buffers } \\
\text { the stream area of from adjacent activities (aim } \\
\text { in water quality and fish preservation), a } \\
\text { 'riparian protection buffer'; while having some } \\
\text { long term benefits, this buffer interferes with } \\
\text { the river view, and also has other negative } \\
\text { effects on the market value of the parcel } \\
\text { situation by a river; (survey of } 705 \text { residents) }\end{array}$ & & $\begin{array}{l}\text { The proximity related and use related objectives combined; the corresponding price } \\
\text { reduction (mean house, and } 50 \text { feet wide buffer) was estimated to } 3-11 \% \text {. }\end{array}$ \\
\hline $\begin{array}{l}\text { Van Kooten (1993), } \\
\text { southeastern } \\
\text { Saskatchewan, } \\
\text { Canada }\end{array}$ & $\begin{array}{l}\text { The impact of wetlands retention (government } \\
\text { agricultural programs that aim at reserving a } \\
\text { portion of the area for waterfowl habit.) on a } \\
\text { typical farm; a survey of } 67 \text { farmers }\end{array}$ & $\begin{array}{l}\text { Calibration of a } \\
\text { theoretical model } \\
\text { of grain producers } \\
\text { when they act to } \\
\text { maximise their net } \\
\text { wealth }\end{array}$ & $\begin{array}{l}\text { Based on the results: estimates the shadow price for marginal land to } \$ 50-60 / \text { acre. This is } \\
\text { twice as much as compensations to farmers (!) }\end{array}$ \\
\hline $\begin{array}{l}\text { Peltola (1998), } \\
\text { Finland }\end{array}$ & $\begin{array}{l}\text { Two data sets: } \\
\text { plotted shore parcels } 1994-95 \\
\text { (n=3649); the parcel is bordering a shore, } \\
\text { which is calculated using a GIS } \\
\text { large shore areas: } 441 \text { observations } 1992-1997 \\
\text { to investigate more water variables: amount of } \\
\text { shoreline; the size of the water body; shape of } \\
\text { the water body; island and sea dummies; the } \\
\text { length and shape of shoreline; shore quality } \\
\text { (development potential) } 1 . .4 \text {; partitioned }\end{array}$ & $\begin{array}{l}\text { Linear, and } \\
\text { logarithmic models }\end{array}$ & $\begin{array}{l}\text { Shore parcels } \\
\text { size of the water-body smallest }(<100 \mathrm{ha})=>\text { largest }(>15000 \mathrm{ha}) \text { : double price; moving } 100 \\
\mathrm{~m} \text { away from the shore reduces the price } 7 \% \text {; time of sale; the sea, and southern Finland, } \\
\text { the most valuable location; there is an interaction effect }=>\text { close to Helsinki. } \\
\text { Large shore areas } \\
\text { Logarithmic: price/ha is } 12-17 \% \text { higher for the higher quality of shore per one unit shore: } \\
1 . .4 \text { scale (building perspective); no price effect with quality of submerged shore } 1 . .4 \\
\text { (recreation); no price effect with quality of water } 1 . .3 \text { (visually) } \\
\begin{array}{l}10 \% \text { amount of shoreline is increasing the price } 2 \% ; 10 \% \text { increase in the size of the water } \\
\text { body }=>2 \% \text {; the length and shape of shoreline has an impact of } 17-26 \% \text { per one unit; R- }\end{array}\end{array}$ \\
\hline
\end{tabular}




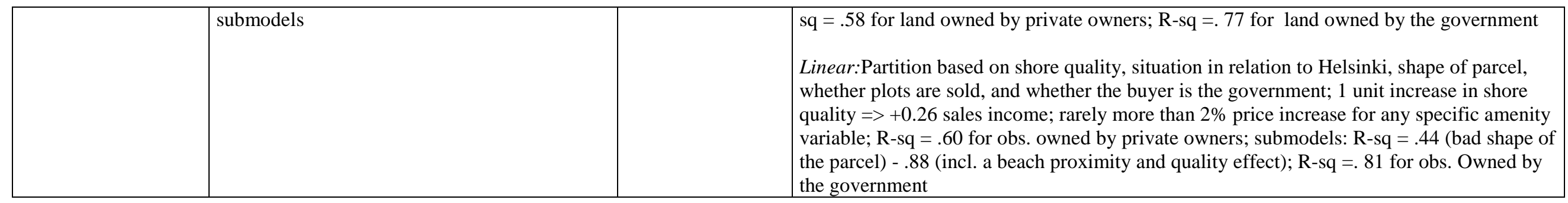

APPENDIX 2: A summary table of the flood/drought impact studies

\begin{tabular}{|c|c|c|c|}
\hline Who?When? Where? & $\begin{array}{l}\text { Research design: method, sample size time- } \\
\text { period, market segment etc. }\end{array}$ & \begin{tabular}{|l|} 
Note on \\
specification?
\end{tabular} & Basic finding regarding flood/drought impact \\
\hline $\begin{array}{l}\text { Holway \& Burby (1990), } \\
\text { 100-years floodplain } \\
\text { areas, US }\end{array}$ & $\begin{array}{l}\text { Hedonic study, floodplain controls, assessed } \\
\text { land value per } 1000 \text { sq. } \mathrm{ft} \text {; variables flood } \\
\text { history, flood control structure; elevation } \\
\text { requirements, and prohibitions on } \\
\text { development for areas that are } 75 \% \text { in } \\
\text { floodplain (year 1985, } \mathrm{n}=306 \text { ) }\end{array}$ & $\begin{array}{l}\text { Inverse semi-log } \\
\text { transformation }\end{array}$ & $\begin{array}{l}\$ 288 \text { loss, if experienced floods; } \$ 689 \text { price premium of flood control structure; } \$ 74 \text { loss } \\
\text { for elevation requirements, and } \$ 188 \text { prohibitions on development; total loss due to the } \\
\text { floods } \$ 1126 \text { (18\%); R-sq. adj. } 0.47-.55\end{array}$ \\
\hline $\begin{array}{l}\text { Chou \& Shih }(2001) ; 13 \\
\text { cities in Taipei } \\
\text { Metropolis, Taiwan }\end{array}$ & $\begin{array}{l}\text { Flood risk defined as effect of flood events } \\
\text { on the short-term price fluctuation of } \\
\text { residential property; actual risk: frequency } \\
\text { of event x consequence (submerged area in } \\
\text { ha); subjective risk, measured with the scale } \\
\text { 0..5, was asked (1992-2000, } n=351 \text { ) }\end{array}$ & $\begin{array}{l}\text { Subjective vs. } \\
\text { frequency risk }\end{array}$ & $\begin{array}{l}\text { The capitalised perceived risk }>\text { the capitalised actual risk; people tend to overestimate } \\
\text { the effect: aversion to move to flood prone areas }>\text { the price reduction caused by markets; } \\
\text { up to } 6.81 \% \text { quarterly price fluctuations for areas with high public's perception of risk. }\end{array}$ \\
\hline $\begin{array}{l}\text { Harrison, Smersh \& } \\
\text { Schwartz (2001); Alachua } \\
\text { County, Florida }\end{array}$ & $\begin{array}{l}\text { Flood zone situation; valuation of homes } \\
\text { located within 100-year flood plains (1980- } \\
97) ; 29,887 \text { property transactions, }\end{array}$ & & $\begin{array}{l}\text { Comparable homes within a flood zone sell on average for less than homes located } \\
\text { outside flood zones (price differential < flood insurance premiums) }\end{array}$ \\
\hline $\begin{array}{l}\text { Hersh \& Wernstedt } \\
\text { (2001/2002); Willamette } \\
\text { Valley, Oregon, } \\
\text { northwestern US }\end{array}$ & $\begin{array}{l}\text { Opportunities and constraints for reducing } \\
\text { vulnerabilities to floods and droughts; } \\
\text { telephone interviews of } 20 \text { water utility } \\
\text { operators }\end{array}$ & & $\begin{array}{l}\text { Drought: } 1 / 9 \text { large utilities reported major impact; additional } 2 / 9 \text { of them reported } \\
\text { moderate impact; } 4 / 10 \text { small utilities reported moderate impact. Flood: } 2 / 9 \text { large utilities } \\
\text { reported major impact; additional } 5 / 9 \text { of them reported moderate impact; } 6 / 10 \text { small } \\
\text { utilities reported major impact; additional } 4 / 10 \text { of them reported moderate impact }\end{array}$ \\
\hline $\begin{array}{l}\text { Eves \& Brown (2002), } \\
\text { England }\end{array}$ & \begin{tabular}{|l|} 
Effect of floods and flood damage on \\
residential property prices across counties \\
after the floodings in Autumns 1998 and \\
$2000 ;$ floods are categorised as regular, 1 in
\end{tabular} & & $\begin{array}{l}\text { I. premium }>10 \% \text { for property close to river/coastline, if no flood potential; discount }< \\
10 \% \text {, if flood potential (discounts reported in only three counties of } 23 \text { ); II. The impact of } \\
\text { the flooding of } 2000 / 2001 \text { on property prices (discount) was reported as follows: } 0: 8 \\
\text { counties; }<5 \%: 10 \text { counties; } 5-10 \%: 6 \text { counties; } 10-20 \%: 6 \text { counties; }>20 \% \text { (severe }\end{array}$ \\
\hline
\end{tabular}




\begin{tabular}{|l|l|l|}
\hline & $\begin{array}{l}50 \text { years and 1 in 100 years; areas may be } \\
\text { prone to inland/river or coastal/tidal } \\
\text { flooding; questionnaire to 51 Charted } \\
\text { Surveyors to identify flood-prone areas }\end{array}$ & flooding): 4 counties. \\
\hline $\begin{array}{l}\text { Eves (2002), Sydney, } \\
\text { Australia; 1984-2000 data lang term processes related to the } \\
\text { thooding problem; to identify areas that are } \\
\text { potentially liable to flooding, using } \\
\text { planning schemes; in New South Wales } \\
\text { three classifications of flood-height levels } \\
\text { => residential development; house sales: } \\
\text { flood-prone } \sim \text { flood-free areas: } \\
\text { flood liability is reported by local } \\
\text { government; data (44 streets): 22 street } \\
\text { flood prone } 22 \text { streets flood-free in lower } \\
\text { market area detached single-family or low } \\
\text { rise medium density residential complexes } \\
\text { total: } 1067 \text { fl. free + 923 fl. prone sales }\end{array}$ & & $\begin{array}{l}\text { The difference was minor 1984-87, but it increased +> 1991; 1987-91; 11 floods were } \\
\text { recorded after 1991: the difference has been decreasing: peak (1991): 22.4\% difference; } \\
\text { low (1986): 5.9\% difference; the risk is similar for both property types }\end{array}$ \\
\hline
\end{tabular}

